\title{
VOLUTODERMINAE (GASTROPODA: VOLUTIDAE) OF CONIACIAN THROUGH MAASTRICHTIAN AGE FROM THE NORTH AMERICAN PACIFIC SLOPE
}

\author{
LOUELLA R. SAUL ${ }^{1}$ AND RICHARD L. SQUIRES ${ }^{2}$ \\ 'Natural History Museum of Los Angeles County, 900 Exposition Boulevard, Los Angeles, California 90007, <lousaul@earthlink.net>; 2Department of \\ Geological Sciences, California State University, Northridge 91330-8266, <richard.squires@csun.edu>
}

\begin{abstract}
Specimens of the large, shallow-marine, volutid gastropod Volutoderma Gabb, 1877, herein recognized only from strata of Late Cretaceous (Coniacian through early Maastrichtian) age in British Columbia, Washington, California, and Baja California have commonly been identified as Volutoderma averillii (Gabb, 1864). This review of available specimens assigns them to two genera: Volutoderma and Longoconcha Stephenson, 1941 .

Twelve species, nine of them new, comprise three morphologic lineages of Volutoderma, i.e., 1) "Typical" includes $V$. querna n. sp., $V$. averillii (Gabb), V. blakei $\mathrm{n}$. sp., V. jalama n. sp., V. perissa $\mathrm{n}$. sp., and possibly Volutoderma? n. sp.; 2) "Angelica" includes $V$. angelica $\mathrm{n}$. sp., V. elderi n. sp., and V. ynezae n. sp.; and 3) "Magna" includes V. santana Packard, V. magna Packard, and perhaps $V . ?$ antherena n. sp. A new species of Longoconcha, L. eumeka, is the first Pacific Slope record of this genus, which has a Gulf Coast and Tethyan Old World distribution. A smaller volutid, Retipirula Dall, 1907 is endemic to the study area and was formerly known only from its type species $R$. crassitesta (Gabb, 1869) of Paleocene age. Two new Retipirula are reported: $R$. calidula of latest Maastrichtian age and $R$. pinguis of Paleocene age.

Only the Volutoderma lineage containing V. averillii has been found north of San Francisco. Recovery of rudist bivalves from formations yielding Volutoderma suggests that these volutes were warm-temperate to subtropical gastropods. Co-occurrences of these gastropods and rudistids may aid in placing the warm-temperate/subtropical boundary during the Late Cretaceous.
\end{abstract}

\section{INTRODUCTION}

$S^{\text {p }}$ PECIMENS OF Volutoderma Gabb, 1877 are moderately common in Pacific Slope shelf deposits of Coniacian through early Maastrichtian age from British Columbia, Canada, to Baja California, Mexico. Gabb (1877) and subsequent early workers attributed to Volutoderma a nearly worldwide distribution in the Late Cretaceous, but only specimens from the Pacific Slope of North America are presently known to display characteristics of Volutoderma.

Material for this study includes type specimens of described taxa, additional collections from their type localities, and specimens from previously unreported localities (Fig. 1). Twelve species of Volutoderma are discussed, nine of them new. Their temporal ranges, as well as their three recognizable morphological lineages, are plotted on Figure 2. The "Typical" lineage ranged temporally from Coniacian to Maastrichtian, and geographically from British Columbia to Baja California (Fig. 1). The "Magna" and "Angelica" lineages are known only from the Campanian, and geographically might not have ranged north of southernmost California (Fig. 3 near $33^{\circ} \mathrm{N}$ ). Specimens of these two lineages have been collected only west of the San Andreas Fault from terranes considered to have been transported northward.

Although this study focuses on Volutoderma, species of two other volutodermine genera, Longoconcha Stephenson, 1941 and Retipirula Dall, 1907, with morphological similarities to Volutoderma are included. Longoconcha eumeka n. sp. ranges from late Campanian into the Maastrichtian and has been recovered from north of Coalinga, Fresno County, California, southward to Arroyo Santa Catarina, Baja California, Mexico. Late Maastrichtian Retipirula calidula $\mathrm{n}$. sp. and late early Paleocene $R$. pinguis $\mathrm{n}$. sp. are known from southern California, but the early late Paleocene species $R$. crassitesta (Gabb, 1869) has been collected from near Clear Lake, Lake County, northern California, south to the vicinity of Arroyo Santa Catarina, Baja California, Mexico.

Post-Turonian California volutodermine diversity was greatest during the middle to late Campanian (Fig. 2). Two lineages disappeared during latest Campanian, but diversity was partially maintained by the addition of Longoconcha to faunas of latest Campanian-early Maastrichtian age. Perhaps owing to unfavorable facies and restricted development of Maastrichtian deposits, late early and late Maastrichtian Volutoderminae are rare. Fewer
Pacific Slope Maastrichtian megafossils, especially from shallowshelf habitats, have been collected, and those collected are, in general, not well preserved or studied.

All available Volutodermine specimens are incomplete. Their anterior siphon is rarely complete, and most larger specimens lack the early whorls. When present, the surface of the spire is usually abraded. Specimens from the Point Loma Formation near Carlsbad, San Diego County, especially of Longoconcha and Volutoderma, provide features not retained by specimens from elsewhere and have helped greatly toward identifying less-informative material.

The specimens studied are mainly from fine-grained, argillaceous sandstone and siltstone. The "Typical" lineage is most abundant in shallow-shelf deposits that probably accumulated at depths below wave base. Occurrences of "Angelica" and "Magna" lineages generally suggest more offshore or somewhat deeper water habitats. An association of a crepiduliform gastropod with the volutes may have developed in the late Campanian (Fig. 11.7, 11.8).

Despite the popularity of volute shells with shell collectors, little is known about the biology of the Volutidae, according to Darragh and Ponder (1998). They noted that although most live and burrow in sublittoral sands, modern volutes range from shallow-water, littoral habitats to abyssal depths. Volutids are carnivorous (C. S. Weaver and du Pont, 1970), and most feed on other mollusks, which they envelop with the foot (B. Morton, 1986), but some deepwater forms prey on echinoderms (Darragh and Ponder, 1998). The protoconch is generally smooth and is commonly of one to three whorls, but it is multiwhorled in some species. All modern volutes produce large eggs in capsules; most eggs develop directly into the crawling stage, and modern volutid hatchlings may exceed $10 \mathrm{~mm}$ (Darragh and Ponder, 1998). In contrast, earliest whorls found on Volutoderma are of less than half that size.

\section{GEOLOGIC AGE CONSIDERATIONS}

The present North American Pacific Slope biostratigraphic ammonite correlations, largely based on Matsumoto (1959a, 1959b; 1960 ), provide a framework for the chronologic ranges of the volutes plotted on Figure 2. The ammonites have been linked to the Geologic Time Scale of Gradstein et al. (2004) by geomagnetic polarity studies (e.g., Ward et al., 1983). The end of the long normal $34 \mathrm{~N}$ is near the Santonian-Campanian boundary (Gradstein et al., 2004). This boundary and the reversal 34N-33R are 
recognized in the Chico Formation along Chico Creek, (Area 6) where Volutoderma querna occurs below and $V$. averillii above the reversal. Although ammonite and Turritella ranges (Fig. 2) aid in defining the chronologic ranges of the studied species, some Pacific Slope ammonites, as noted by Matsumoto (1959b) regarding Metaplacenticeras Spath, 1926, need revision. Matsumoto (1984) later referred M.? bowersi Anderson, 1958 to Hoplitoplacenticeras? Spath, 1926, but made no other revision. The occurrence of $V$. blakei with $H$. ? bowersi suggests that $H$. ?bowersi is older than M. pacificum (Smith, 1900) and may be younger than $H$. vancouverense (Meek, 1858).

Additionally, Figure 2 uses the Eubaculites carinatus Zone following Cobban and Kennedy (1995) who considered E. ootacodensis of Matsumoto (1959a) a synonym of E. carinatus (S. G. Morton, 1834). Figure 2 also reflects the recognition by Cobban and Kennedy (1995) of Baculites lomaensis Anderson, 1958 in the Prairie Bluff Chalk of Mississippi and Alabama, associated with ammonites of the Discoscaphites iris assemblage zone and thus suggesting an age as young as early late Maastrichtian.

\section{PALEOGEOGRAPHIC AND PALEOCLIMATIC IMPLICATIONS}

The studied specimens have small multiwhorled protoconchs, in contrast to the larger pauciwhorled protoconchs characteristic of modern volutes. Fisher et al. (1964) inferred that a multiwhorled small protoconch in volutes is indicative of a relatively long pelagic stage and that decrease in protoconch whorl number in Paleocene and Eocene Gulf Coast volutes was recording shortening of the pelagic stage. A shorter pelagic stage could imply post-Cretaceous changes from planktotrophic larvae toward direct-developing juveniles. Cenozoic volutes having direct development have acquired an array of notably large, bulbous, odd, and secondary protoconchs. Direct development with "crawlaway larvae," as in Recent taxa, has resulted in many locally distinct volute populations (Darragh and Ponder, 1998).

Both Gabb (1877) and Dall (1907), in noting the wide paleogeographic distribution of early fossil volutes, suggested that it was facilitated by a lengthy pelagic stage. Dall (1907) especially noted the wide distribution of a considerable diversity of gastropod shells with volutid characteristics in the Cenomanian, among them being Carota Stephenson, 1952, which occurs in Europe, Middle East, India, North Africa, and North America and ranges probably into the Santonian. Carota is similar to Volutoderma and to Longoconcha. It preceded the latter two in the geologic record and was geographically more widespread. Our finding that $\mathrm{Vol}$ utoderma had an east Pacific rather than global distribution perhaps indicates that even before reduction of protoconch whorl number, its planktotrophic larval stage had been reduced.

On the Pacific Slope, deposits yielding Late Cretaceous fossil volutes are at present found between latitudes $52^{\circ} \mathrm{N}$ to $29^{\circ} 30^{\prime} \mathrm{N}$ (Fig. 1). The Late Cretaceous paleomagnetic pole of Butler et al. (2001) is in northern Alaska, and Lund and Bottjer (1992) placed the western margin of the North American craton $11-15^{\circ}$ north of its present position. Also, during the past quarter century postmid-Cretaceous northward transport of up to $4,000 \mathrm{~km}$ with respect to the craton has been proposed for some terranes along the North American Cordilleran margin (Butler et al., 2001). Areas west of the San Andreas Fault are considered by most geologists to have been moved northward from 300 to $500 \mathrm{~km}$ (Fig. 1, Areas $8,10,12-22)$ in post-Cretaceous time, and additional travel distances have been proposed for individual terranes (especially Areas 8,10,15) (Dickinson and Butler, 1998, and references therein). The Baja British Columbia (Baja B.C.) hypothesis suggested transport of Nanaimo Basin deposits of southern British Columbia and northern Washington (Fig. 1, Areas 1 and 2), from a depositional latitude at near $25^{\circ} \mathrm{N}$, northward for up to $3,500 \pm$ $800 \mathrm{~km}$ (Ward et al., 1997, and additional references therein). An alternative interpretation of geophysical data by Butler et al. (2001) used only a northward translation of $\sim 1,000 \mathrm{~km}$. Using compaction-corrected paleomagnetic paleolatitudes, Kodama and Ward (2001) suggested a lesser northward transport of up to 1,500 $\mathrm{km}$ for the Nanaimo Group from a depositional site not farther south than $40^{\circ} \mathrm{N}$ (i.e., northern California).

$\mathrm{Co}$-occurrence of rudists and Volutoderma in the same formation (see Figs. 1 and 3) suggests that the studied Volutoderminae dwelt in subtropical to warm-temperate waters. Rudists serve as indicators of at least marginal tropicality because of their widely reported low-latitude occurrence (e.g., Sohl, 1987; Johnson, 1999). Kodama and Ward (2001) considered reef- and bank-forming rudists such as Coralliochama to be better indicators of tropical-water masses than other mollusks. Judging from their distributions in the strata, rudists and volutes were not inhabiting a common ecotope. Where rudists are especially abundant, as in the Rosario Formation at Punta Banda (Area 20), northern Baja California, volutes are extremely rare; at localities in the same formation which have a more diverse molluscan fauna, disarticulated and broken rudist valves are common to rare. Additionally, as distinctive rudist shell structure makes possible the recognition of rudist shell fragments that have been distributed postmortem, their latitudinal presence can be inferred beyond their ecologic niche.

Figure 3 plots both modern latitude and probable Cretaceous latitude for the studied volutes, in order that a subtropic/warm temperate boundary can be inferred despite the left lateral, northward offset along the San Andreas Fault. Latitudinal changes of this boundary from north of $40^{\circ}$ in the Turonian to less than $35^{\circ}$ in the Campanian are suggested in Figure 3. Turonian rudists have been found as far north as southern Oregon in the lower Hornbrook Formation (Anderson, 1958). Although the apparent absence of rudists in the upper Hornbrook could result from incomplete collecting, their absence agrees with the restriction of rudists and of the Tethyan Realm subsequent to the Turonian that has been noted by Sohl (1987). Turonian is the youngest age during which rudist remains are known to have been deposited east of the San Andreas Fault in California sediments, whereas all North Pacific Slope Coniacian through Maastrichtian rudists have been recovered from west of the San Andreas Fault. Presence of rudists as far north as Gualala (Fig. 1, Area 8) in deposits of Campanian and Maastrichtian age registers the northward movement of the terranes west of the San Andreas Fault, but the inferred depositional latitude, derived from Dickinson and Butler (1998) for Area 8 on Figure 3, may indicate deposition too far north for elements of the fauna.

Various terrane transports cause offsets in an inferred subtropic/ warm temperate boundary. Figure 3 attempts to remove the offsets and show paleotemperature changes. Work on Cretaceous mollusks by Squires and Saul (2006) supports the contention that the Nanaimo Group was deposited not any farther south than northern California. The diffuse tropic/warm temperate boundary of Figure 3 is based on data in the following discussions of the Coniacian through Maastrichtian volutes. Despite the gaps in the fossil record, there is a correspondence between the temperature highs and lows generated in Figure 3 and those recorded by Frakes (1999, p. 51, fig. 1).

Abbreviations. - The following institutional abbreviations are used: ANSP = Academy of Natural Sciences of Philadelphia; CASG = California Academy of Sciences, Geology; CIT = California Institute of Technology (collections at LACMIP); GSC = Geological Survey of Canada; LACMIP = Natural History Museum of Los Angeles County, Invertebrate Paleontology; RBCM $=$ Royal British Columbia Museum, Victoria; SDNHM = San Diego Natural History Museum; UCLA = University of California, Los Angeles (collection at LACMIP); UCMP = University of California, Berkeley, Museum of Paleontology; USGS = United States Geological Survey, Menlo Park (collection now at UCMP); USNM = United States National Museum; VIPM = Vancouver Island Paleontological Museum in Qualicum Beach, Vancouver Island, British Columbia. 


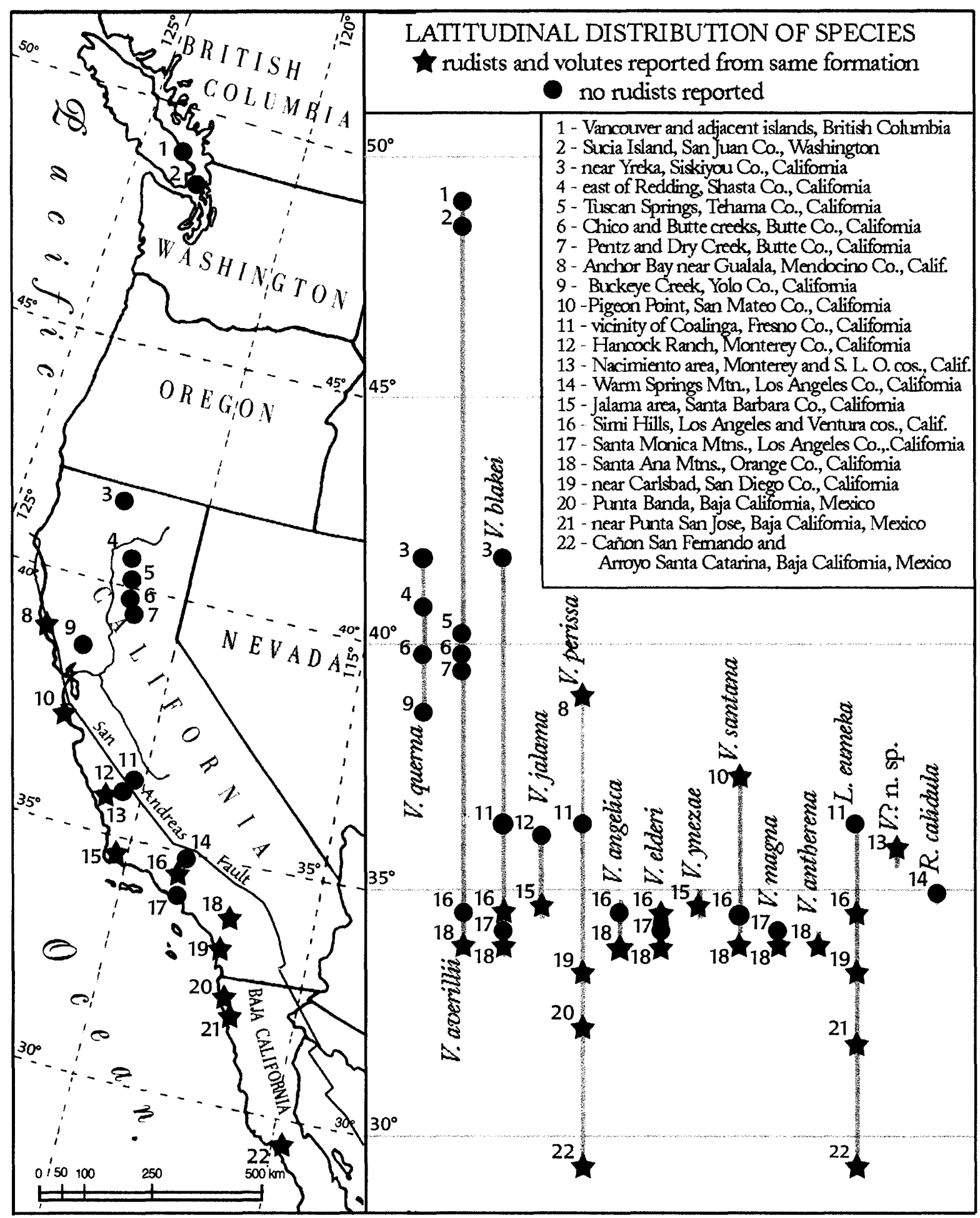

FIGURE 1-Index map with numbered areas from which studied specimens of Late Cretaceous volutes were collected. Map latitudes projected onto righthand box of figure. Latitudinal range of species depicted by bars. Areas west of San Andreas Fault have been moved 300-500 km northward during postCretaceous time. Areas where rudists have been reported from the same formation that has yielded volutes marked by star; areas where rudists are not reported from the same formation marked by circles. See Figure 2 for age of species.

The photographs (Figs. 4-11) of the specimens are arranged in approximately ascending growth size and specimens were coated with ammonium chloride.

See Appendix for locality descriptions or LACMIP locality descriptions at (ip.nhm.org) or in the Supplemental archive of Journalofpaleontology.com.

\section{SYSTEMATIC PALEONTOLOGY}

Class GASTROPODA Cuvier, 1797

Family VOLUTIDAE Rafinesque, 1815

Discussion.--In shell shape and columellar folds, Volutoderma spp. from the Pacific slope of North America display features 


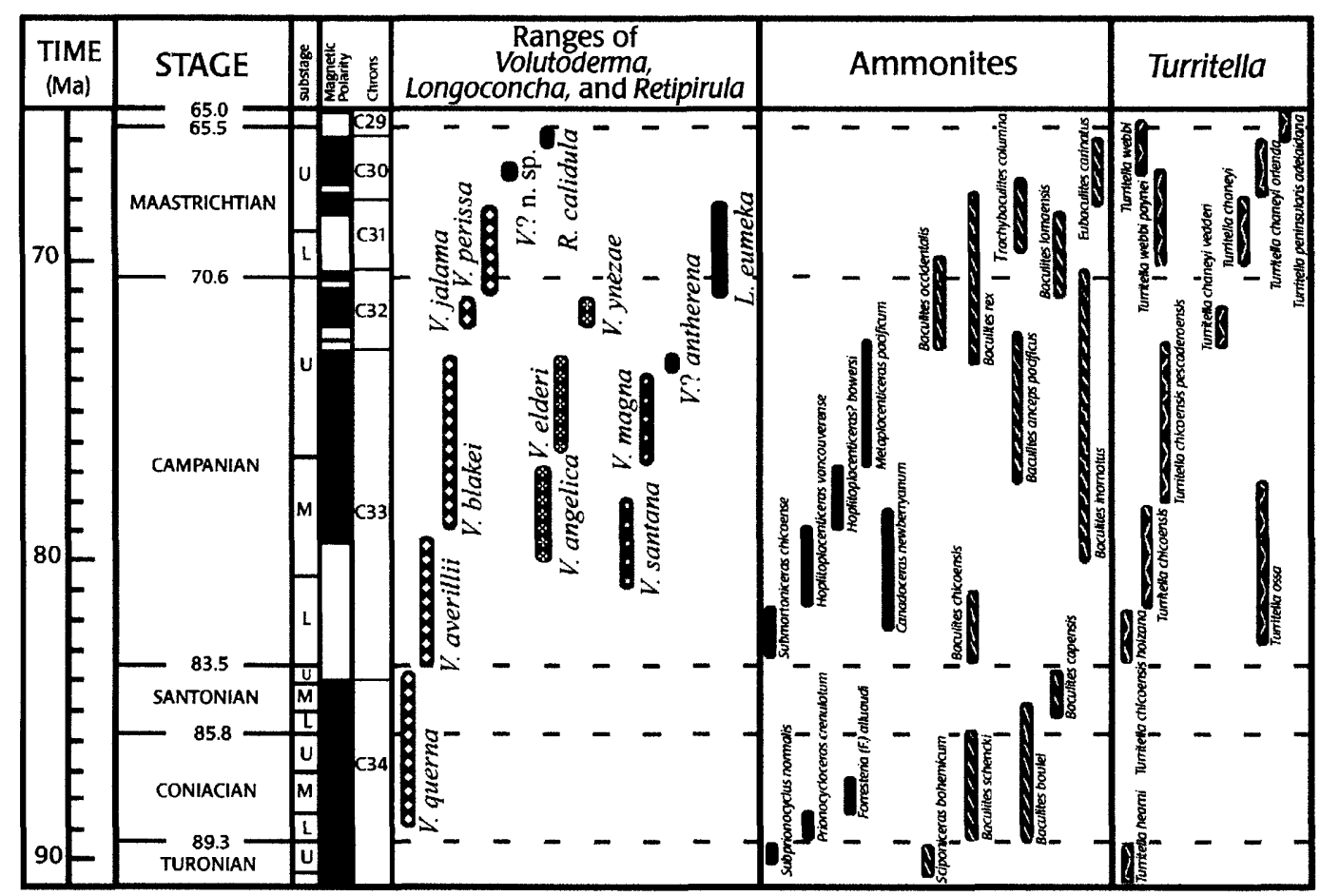

Figure 2-Correlation chart. Age ranges of Cretaceous volutes from this paper. Pattern on bars distinguish three Volutoderma lineages: "Typical" diamonds, "Angelica" crosses, "Magna" spangles. Ammonite ranges from Matsumoto (1959b, 1960), Ward (1978a), and Elder and Saul (1996). Baculite ranges from Matsumoto (1959a, 1960), Ward (1978b), Haggart and Ward (1984), and Cobban and Kennedy (1995). Turritellas after Saul (1983). Geologic ages and magnetostratigraphy after Gradstein et al. (2004, fig. 19.1).

considered characteristic of the family Volutidae by Darragh and Ponder (1998), with the exception that early whorls of Volutoderma are very small whereas modern volutes characteristically have larger, more bulbous protoconchs (Bandel, 2000, 2003). The large protoconchs have been considered as indicating lecithotrophic rather than planktotrophic development of the young (Bandel, 2003), but as the change from very small to large protoconchs does not appear to have been abrupt in the volutes, nor to have occurred simultaneously in all lineages, we retain the Volutoderminae within Volutidae.

\section{Subfamily VolutodERMINAE Pilsbry and Olsson, 1954}

Diagnosis.-Shell elongate or broadly fusiform to coniform; spire shorter than aperture; ultimate whorl large, comprising most of shell, its base not contracted but passing with gradual slope into long anterior canal; protoconch small, multiwhorled; columella with one to five columellar folds; sculpture commonly strong and of both axial and spiral ribs, but may be reduced.

Discussion.-Although Gabb (1877) noted the protoconch differences between modern volutes and the Cretaceous volutiform species he assigned to Volutoderma, he considered that their shell shape, columellar folds, and type of sculpture placed these forms in the Volutidae.

Rough, crinkled sculpture, scaly growth-line sinus on the ramp, and small protoconch have been cited as reasons to group volutodermine gastropods with Pholidotoma Cossmann, 1896 and Beisselia Holzapfel, 1889 and place them in familial categories included in Turridae (Cossmann, 1896; Kiel and Bandel, 2003), in Pholidotomidae (Cossmann, 1909; Ponder and Warén, 1988), in Pyrifusidae (Bandel, 2000; Bandel and Dockery, 2001), in Pholidotominae (Cossmann, 1896; Ponder and Warén, 1988; Bandel, 2003; Bouchet et al., 2005). Ponder and Warén (1988) listed Volutoderminae and Volutomorphinae Dzhalilov (also transliterated as Djalilov), 1977, as junior synonyms of Pholidotominae, but Bandel (2003) used Volutoderminae. Bouchet et al. (2005, p.
255) spelled the subfamily Volutodermatinae (following Latin rules) and included it in Pholidotomidae.

Bandel (2003) emphasized the systematic importance of the trace of the posterior sinus against the suture, but the distinct posterior sinus that Cossmann (1896) ranked highly for including genera in Pholidotomidae is, in our view, present in other lines of gastropods (e.g., Perissityidae Popenoe and Saul, 1987), in which the sinus migrates from shoulder to suture. In the California volutes the sinus is well developed in early forms (e.g., Turonian Carota dilleri (White, 1889) (Saul and Popenoe, 1993, figs. 97, 107) and broader and shallower in Coniacian Volutoderma querna n. sp. (Fig. 4.9). In early Campanian $V$. averillii, the growth line is notched at the suture and nearly straight across the ramp (Fig. 5.7).

Although Pholidotoma Cossmann, 1896 and Beisselia Holzapfel, 1889 have a posterior sinus similar to that of Carota, they are without folds on the columella (Cossmann, 1896, 1909). We follow Pilsbry and Olsson (1954) in excluding them from Volutoderminae, and use the original spelling because it has long been common usage (e.g., Sohl, 1964; Bandel, 2000; Bandel and Dockery, 2001).

\section{Genus Volutoderma Gabb, 1877}

Type species.- “ $V$. navarroensis, Shum., Gabb, Paleontology of California, vol.i., pl. 19, fig. 6," by original designation Gabb, 1877 , p. $289=$ Volutoderma navarroensis (Gabb, 1877), NOT Volutilithes navarroensis Shumard, 1861. Volutoderma navarroensis $(\mathrm{Gabb}, 1877)=[$ Fusus averillii Gabb, 1864]. Tuscan Springs, Tehama County, northern California. Early Campanian.

Diagnosis.-Shell fusiform, of medium to large size with long flexed anterior canal; ramp sloping, set off from whorl by sculpture or by weak to moderate angulation, bordered posteriorly by spirally ribbed collar, on spire ramp crossed by strong, raised, imbricate growth lines that join posterior edge of parietal callus shield. Protoconch small. Sculpture of more or less definite, rounded axial ribs, strongest near shoulder, fading anteriorly and overridden by narrow 


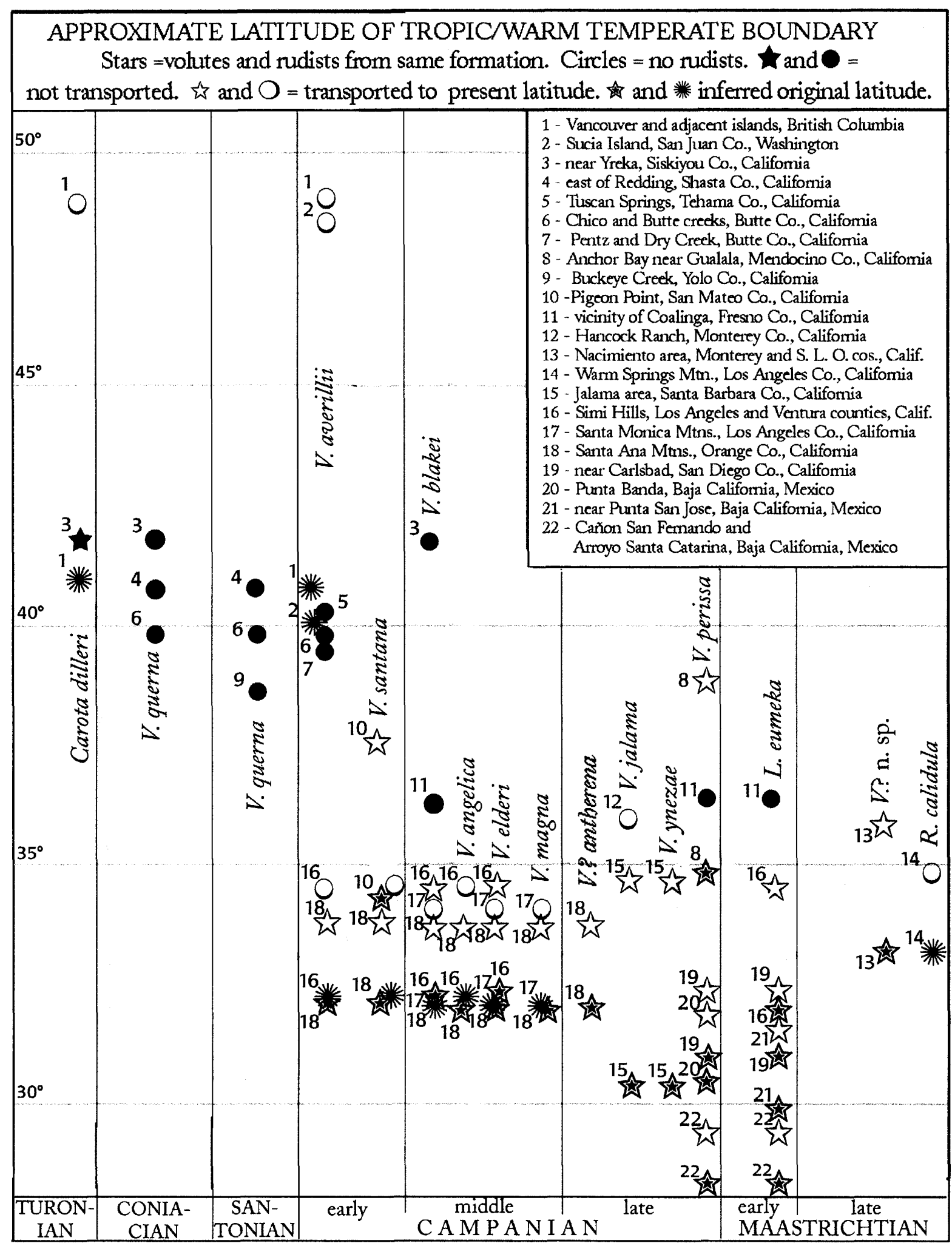

FIGURE 3-Approximate Late Cretaceous latitude of subtropic/warm-temperate boundary (grey bar) inferred from northern-most latitude provided by rudistid occurrence with a volutodermine species. Species plotted roughly within age but see Figure 2 for age range of species. Present latitude from Figure 1; inferred Cretaceous latitude from reconstructions of Dickinson and Butler (1998) and Kodama and Ward (2001). Pigeon Point Terrane with V. santana and Gualala Block with $V$. perissa n. sp. provide northward excursions of tropic boundary using these reconstructions. Turonian occurrence of rudists with Carota dilleri from lower Hornbrook Formation of northern California and southern Oregon but of $C$. dilleri without rudists from basal Nanaimo Group on Sidney Island, British Columbia, suggest possibility of Turonian subtropic boundary north of $40^{\circ}$. Late Campanian drop in subtropic boundary based on Jalama Formation occurrences is probably artifact of geologic record gaps. If rudist occurrences of El Piojo Formation are of late Campanian age, no drop would exist. 

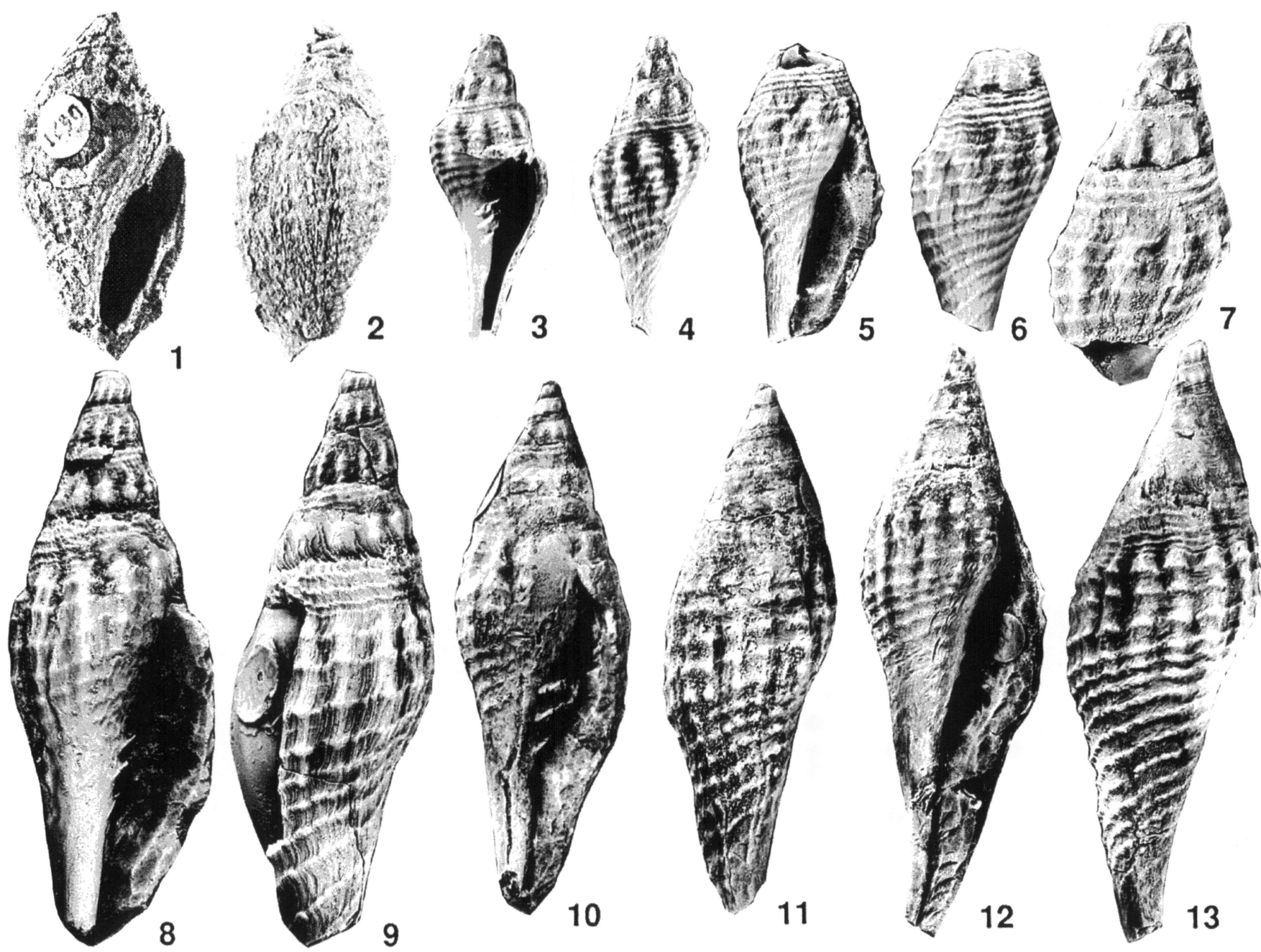

Figure 4-Carota cf. C. dilleri White, 1889 and Volutoderma querna n. sp. from Pacific Slope of North America. 1, 2, Carota cf. C. dilleri, LACMIP 13360 from LACMIP 10135, ×1. 3-13, Volutoderma querna n. sp.; 3, 4, paratype, LACMIP $13155, \times 1.8 ; 5$, 6, paratype, LACMIP 13162, ×2.2; 7, paratype, LACMIP 13161, ×2.7; 8, 9, paratype, LACMIP 13160, ×1.8; 10, 11, paratype, LACMIP 13156, ×1.3; 12, 13, holotype, LACMIP $13154, \times 1.1$.

spiral cords; spiral cords commonly forming spirally elongate nodes on axial ribs; earliest whorls with strong distant axial costae and weaker spiral lines. Aperture elongate, outer lip commonly a little reflexed, especially posteriorly; inner lip callus well developed; parietal callus shield present, commonly expanded posteriorly across previous suture; three oblique columellar folds approximately medially placed on columella.

Occurrence.-Pacific Slope of North America, British Columbia to Baja California. Coniacian to late Maastrichtian.

Discussion.-Gabb (1877) indicated as type of Volutoderma the species from the lower Campanian Chico Formation at Tuscan Springs, which he had figured in 1864 as Volutolithes navarroensis Shumard, 1861. Stewart (1927) recognized that the specimen figured by Gabb is actually an adult of Fusus averillii Gabb, 1864, the type specimen of which is also from Tuscan Springs.

Despite Stewart's (1927) notation that the type of Volutoderma was by original designation of Gabb, the designation and the name of the type species have continued to be misunderstood (e.g., Anderson, 1958; Ludvigsen and Beard, 1994; Bandel,
2000). Gabb (1864) identified specimens from Tuscan Springs, Tehama County, California as Volutilithes navarroensis Shumard, and figured one of them on plate 19, figure 56. In 1869, Gabb listed the California specimens as $V$. navarroensis, Shum.? and indicated that he was questioning his earlier identification. Gabb (1877, p. 289), cited his 1864 figure, and established the genus Volutoderma on " $V$. navarroensis Shum., Gabb, Palæontology of California, vol. i, pl. 19, fig. 6" (fig. 6 = error for 56). Because Gabb questioned his 1864 identification and cited his plate 19, figure 56 as typical of Volutoderma, this citation involves three articles of the ICZN (1999) code: Article 67.2.1, the species cited is eligible for type fixation; Article 67.13, the misidentified species so fixed becomes a new nominal species; and Article 69.2.4, the species thus designated Volutoderma navarroensis (Gabb) is the nominal species (and Volutolithes navarroensis Shumard is not). Volutoderma navarroensis (Gabb, 1877) is a junior synonym of Fusus averillii Gabb, 1864.

Of the pre-Coniacian Pacific Slope volutes, the one most similar to Volutoderma is Carota, which differs from Volutoderma

Figure 5-Volutoderma averillii (Gabb, 1864) from Pacific Slope of North America. 1, 2, hypotype, LACMIP 13170, ×1.9; 3, hypotype, LACMIP 13169, $\times 1.75 ; 4,5$, hypotype, RBCM.EH2004.013.0001, $\times 1.8 ; 6$, hypotype, LACMIP $13172, \times 1 ; 7$, hypotype, LACMIP 13171, ×1; 8, hypotype, LACMIP 13168, $\times 1$; 9, hypotype, LACMIP 13173, ×1.01; 10, paralectotype of Volutoderma suciana Dall, 1907, GSC 5786d from Sucia Island, ×0.92; 11, 12, lectotype of Volutoderma suciana, GSC 5786c from Sucia Island, $\times 0.93 ; 13,14$, hypotype, UCR 3435/1, $\times 0.73$. 

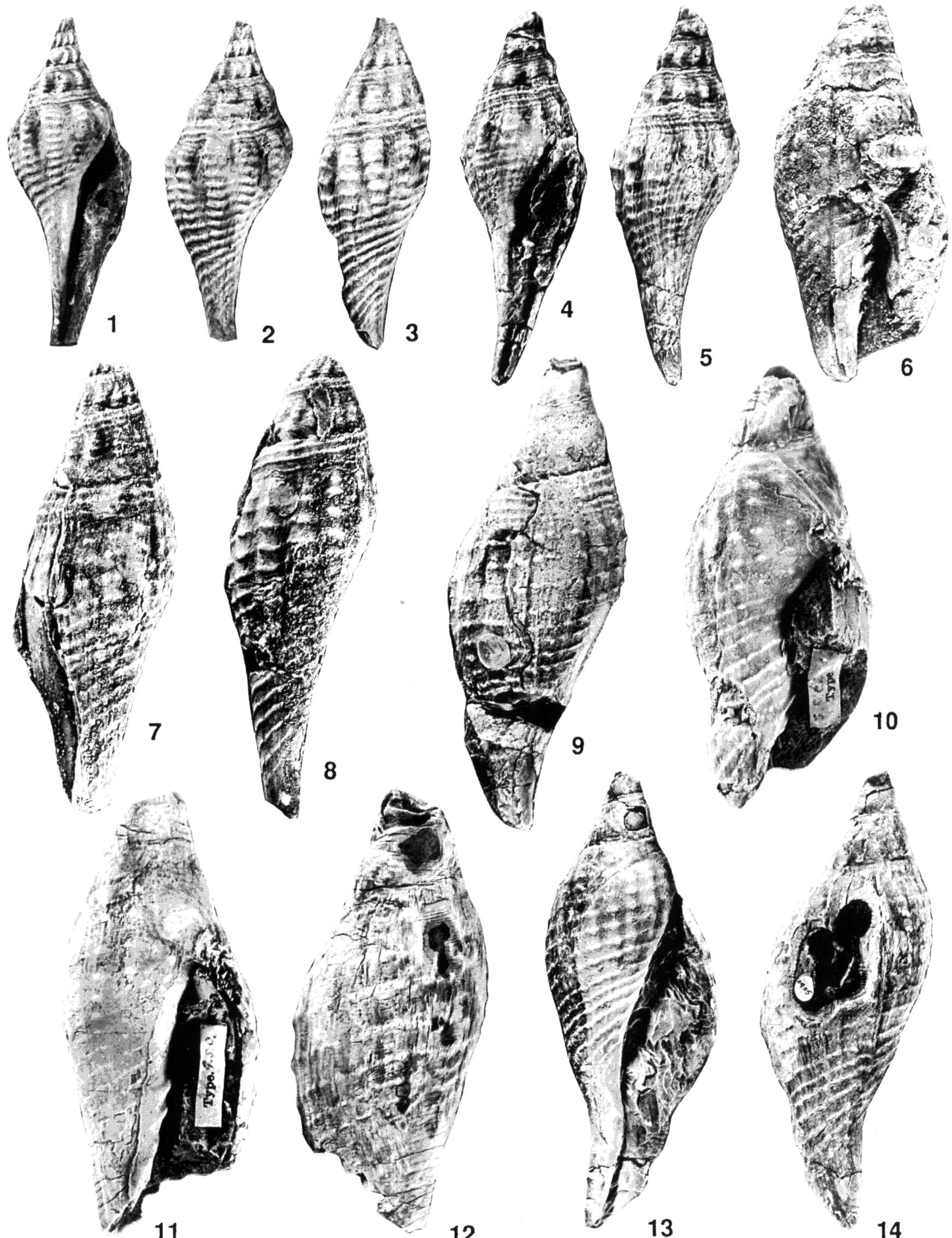

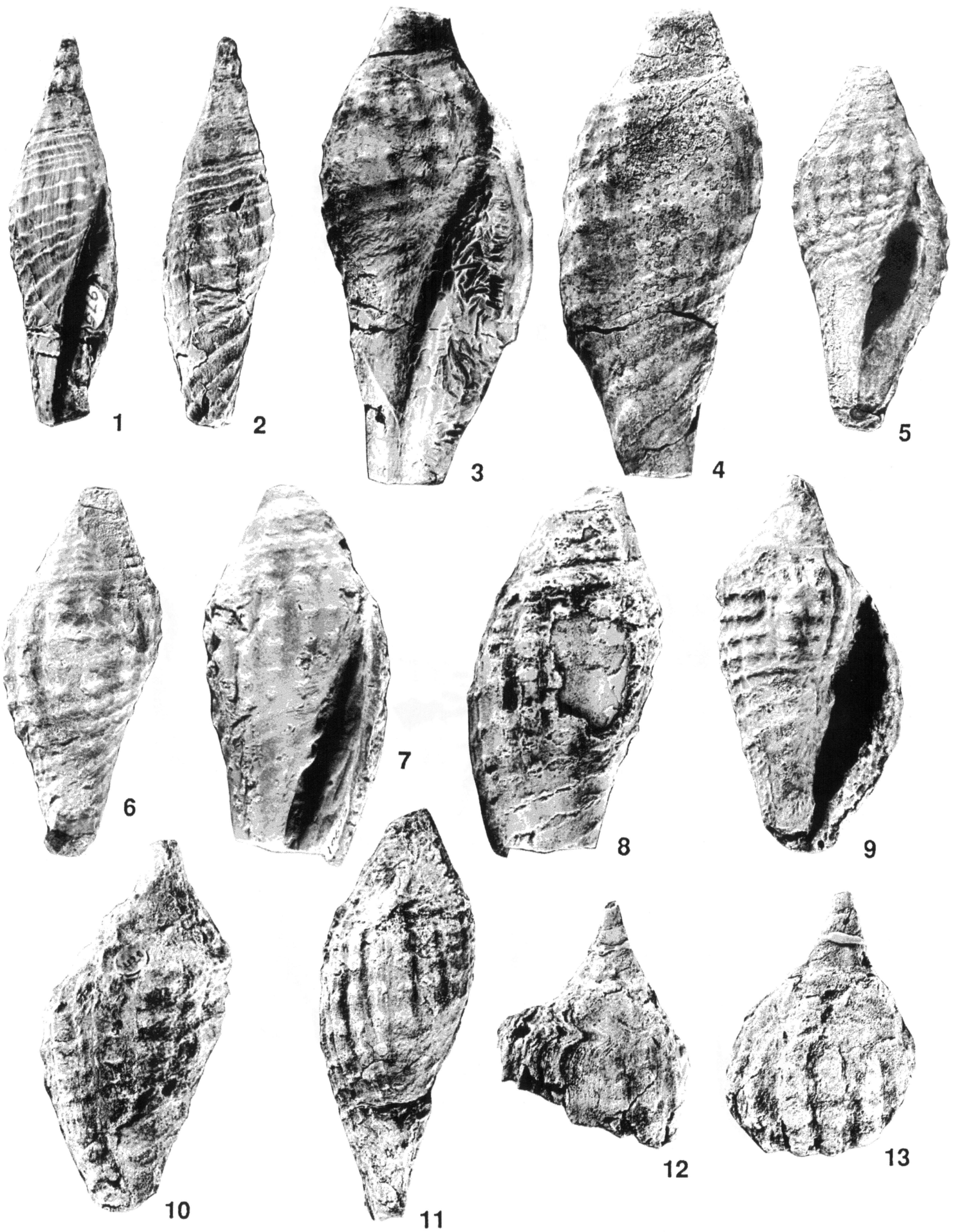

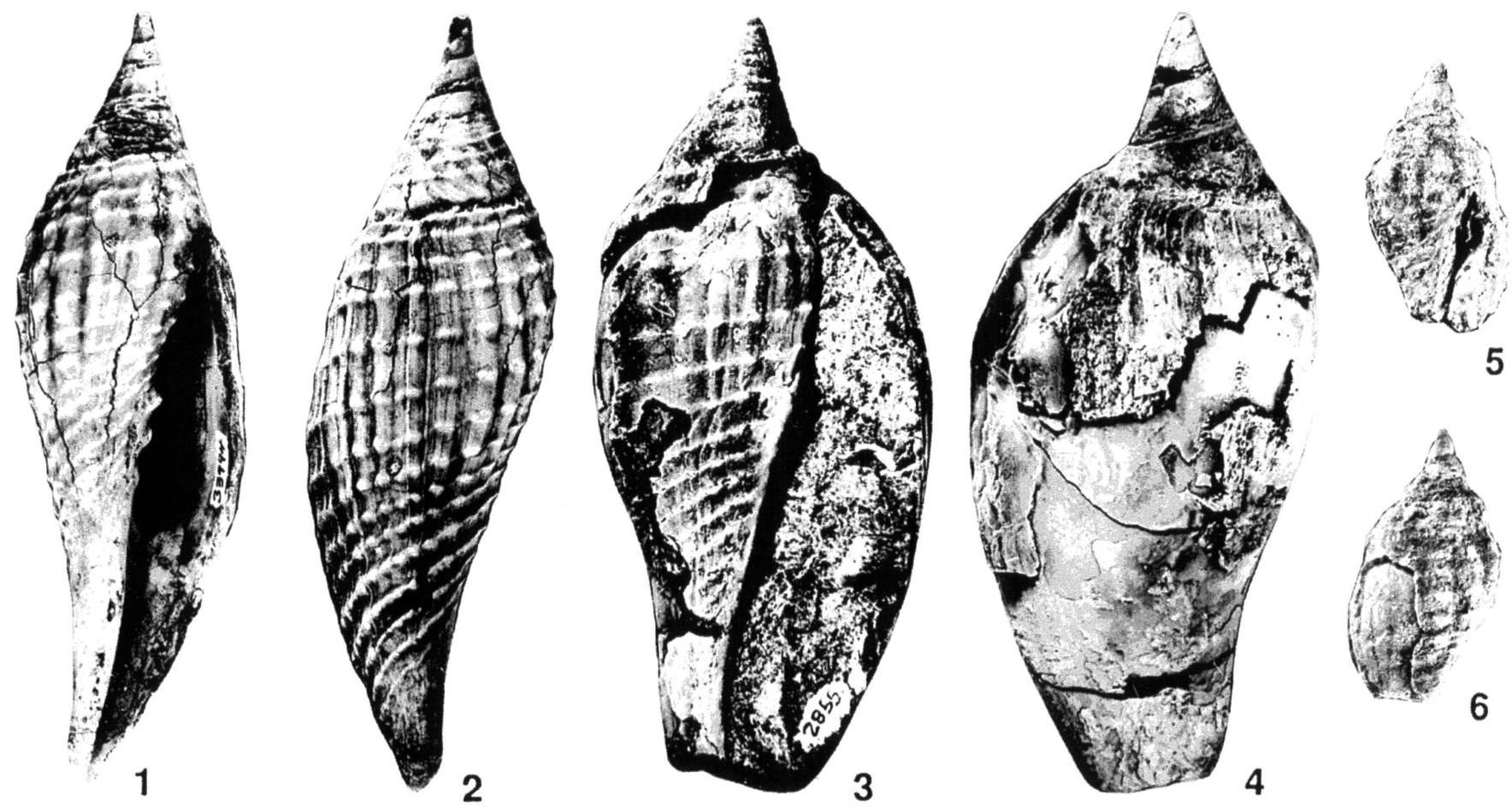

Figure 7-Volutoderma spp. from the Pacific slope of North America. 1-4, Volutoderma perissa n. sp.; 1, 2, holotype, SDNHM 33994, ×1. 3, 4, Paratype, LACMIP $13185, \times 0.75 .5$, 6, Volutoderma ? n. sp., hypotype, LACMIP $13217, \times 1$.

in three features: growth line, development of a parietal shield, and width and spacing of spiral cords. The growth line of Carota has a well-defined sinus immediately rampward of the shoulder. Growth lines in Volutoderma querna n. sp. (Fig. 4.9), the geologically oldest species, have a broader, more adapical sinus on the ramp than in Carota (Fig. 4.2), but geologically younger species of Volutoderma (Fig. 5.14) have a sinus at the suture. Both Carota dilleri (White, 1889) and C.? mitraeformis (Gabb, 1869) have a parietal callus, but neither have Volutoderma's distinctive callus deposits that obscure the sculpture on the spire whorls, especially near the suture. On Carota the spiral cords and interspaces are of similar width, as are the cords and interspaces of juvenile $V$. querna and $V$. averillii, but the cords of geologically younger Volutoderma spp. are a third or less as wide as the interspaces. Additionally, in mature Volutoderma the cords are of three types: the ramp cords are fine and unnoded; the cords between shoulder and siphonal neck are largest, noded across the axial costae, and have widest interspaces; and the cords of the siphonal neck are unnoded. The sculpture of C.? mitraeformis, which has incipient differentiation of the spiral sculpture, is slightly more similar to the sculpture of Volutoderma than that of $C$. dilleri. A few, unfortunately incomplete, specimens of Carota cf. C. dilleri (e.g., Fig. 4.1, 4.2) of late Turonian age from southern California also show minor differentiation of the spiral cords.

In considering Volutoderma "characteristic of" and "peculiar to" Cretaceous rocks, Gabb (1877, p. 289) included species from Europe, North America, and India. Dall (1907) also defined Volutoderma broadly, gave it a global distribution, and provided local supraspecific names for locally speciated but similar forms that arose at geographically separated centers. He separated from typical Volutoderma, at least subgenerically, Rostellinda Dall, 1907 from India, Rostellana Dall, 1907 and Rostellaca Dall, 1907 from Europe, and Volutomorpha Gabb, 1877 from America. Volutomorpha differs from Volutoderma in being fully glazed by a callus coat, and Sohl (1964) found it to be mainly from Gulf and Atlantic Coastal Plain deposits. Volutoderma has at least three columellar folds, although in some species they are not visible from the aperture, whereas Volutomorpha commonly has one dominant, very oblique fold and one or two subsidiary folds. Species later assigned to Longoconcha, including Volutilithes navarroensis Shumard, 1861, were evidently considered by Dall (1907) to be typical Volutoderma, as were the Pacific Slope species with the exception of Scobinella dilleri White, 1889, of Turonian age, which Dall (1907) listed as Volutoderma (Rostellinda) dilleri. Whorls of Volutoderma are consistently inflated posterior to midwhorl and are less slender than in Longoconcha, which has a body whorl conspicuously flattened on the side. Sohl (1964) gave a range of Coniacian to Maastrichtian for species of Longoconcha, most of which are from Atlantic and Gulf Coast, but he also included Mitra murchisoni Müller, 1851 from Germany and Voluta elongata Sowerby of d'Orbigny, 1843 from France and Africa. Kollmann (2005) found d'Orbigny's specimens to differ specifically from Sowerby's and redescribed them as Carota megalocostata Kollmann, 2005 (p. 139), of late Turonian age. A midde Santonian steinkern from Germany figured by Kiel and Krüger (2006, p. 688, fig. 15) as Volutoderma elongata is more fusiform and finely sculptured than Volutoderma. Two specimens, figured as Voluta conspicua Coquand by Pervinquière (1912, p. 74 , pl. 6 , figs. 10, 11) from the Coniacian of Tunisia, appear to be internal molds; their flattened whorl sides resemble those of Longoconcha more than those of Volutoderma. Two similar molds

FIGURE 6-Volutoderma spp. from the Pacific slope of North America. 1-4, Volutoderma blakei $\mathrm{n}$. sp.; 1, 2, paratype, LACMIP 13175, $\times 1.3 ; 3,4$, holotype, LACMIP $13174, \times 0.66$. 5-13, Volutoderma jalama n. sp.; 5, 6, paratype, LACMIP $13180, \times 1.4 ; 7,8$, paratype, LACMIP 13181, $\times 1.4 ; 9$, 10, paratype, LACMIP $13183, \times 1.02 ; 11$, holotype, LACMIP $13179, \times 0.79 ; 12,13$, paratype, LACMIP $13184, \times 1.13$. 


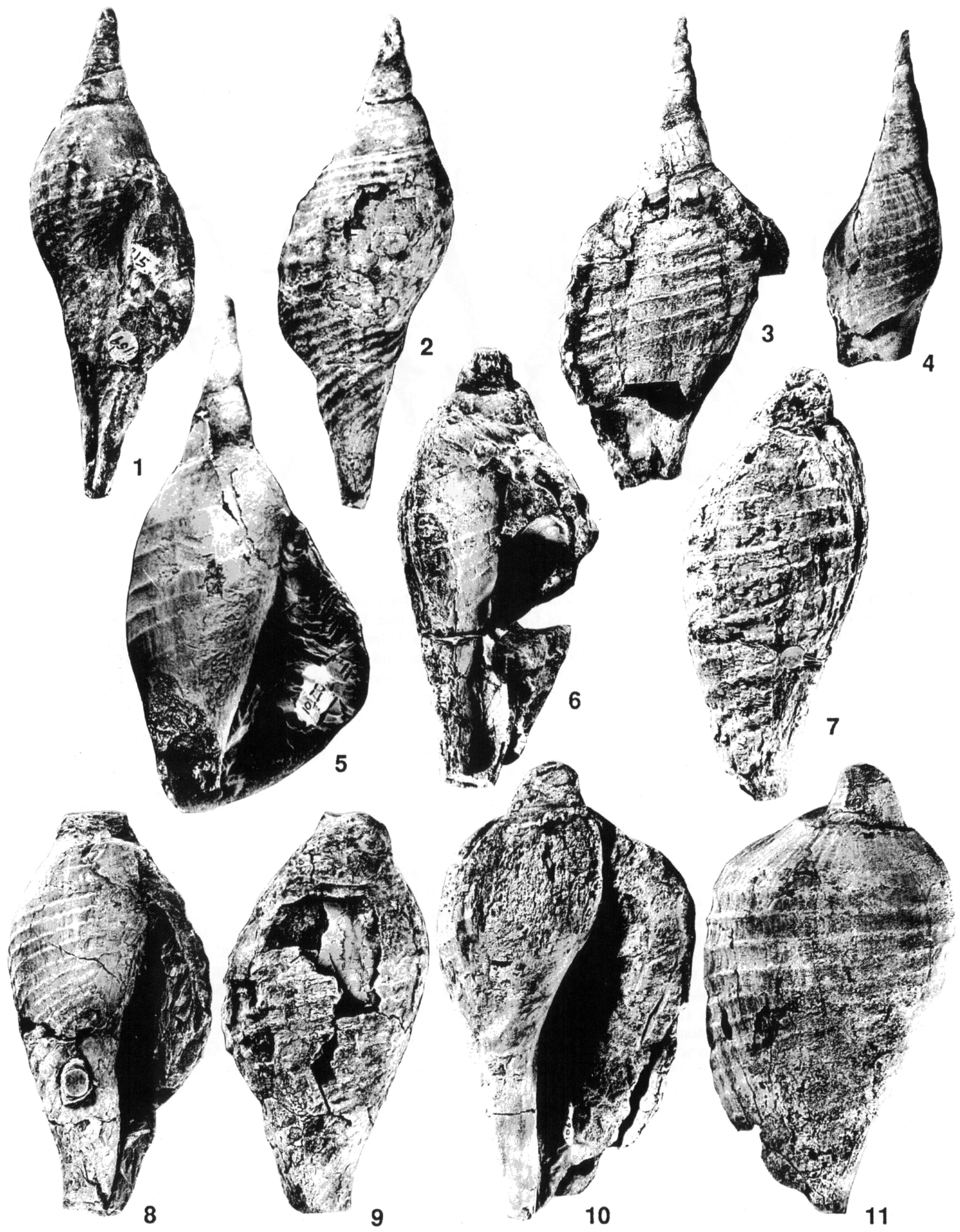

FigURE 8-Species of Volutoderma angelica group from the Pacific slope of North America. 1, 2, Volutoderma angelica n. sp., holotype, LACMIP 13190 , $\times 0.95$. 3-7, Volutoderma elderi n. sp.; 3, paratype LACMIP 13358, $\times 0.72 ; 4$, paratype $13201, \times 0.9 ; 5$, holotype $13197, \times 0.76 ; 6,7$, paratype $13202, \times 0.76$. $8-11$, Volutoderma ynezae n. sp., 8, 9, paratype, LACMIP $13206, \times 0.84 ; 10,11$, holotype, LACMIP $13204, \times 0.68$. 


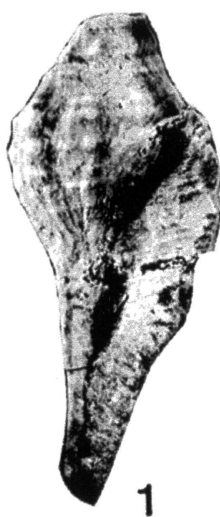

1

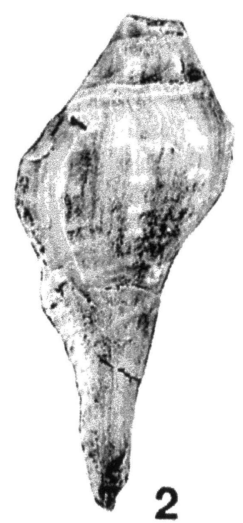

2

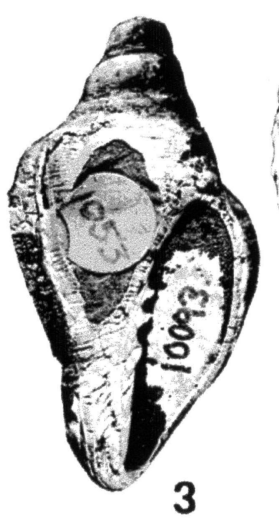

3

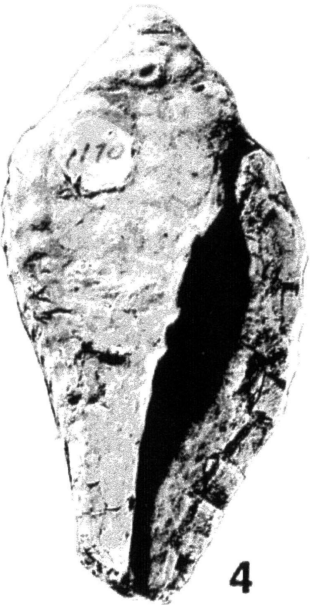

4

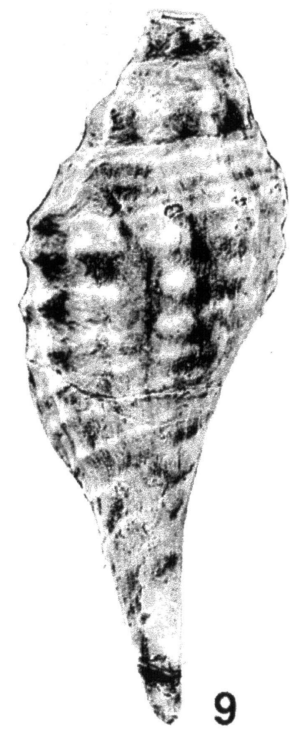

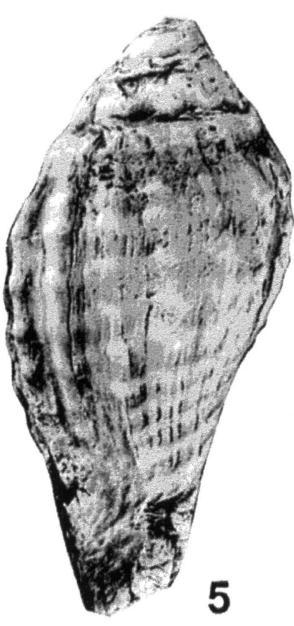
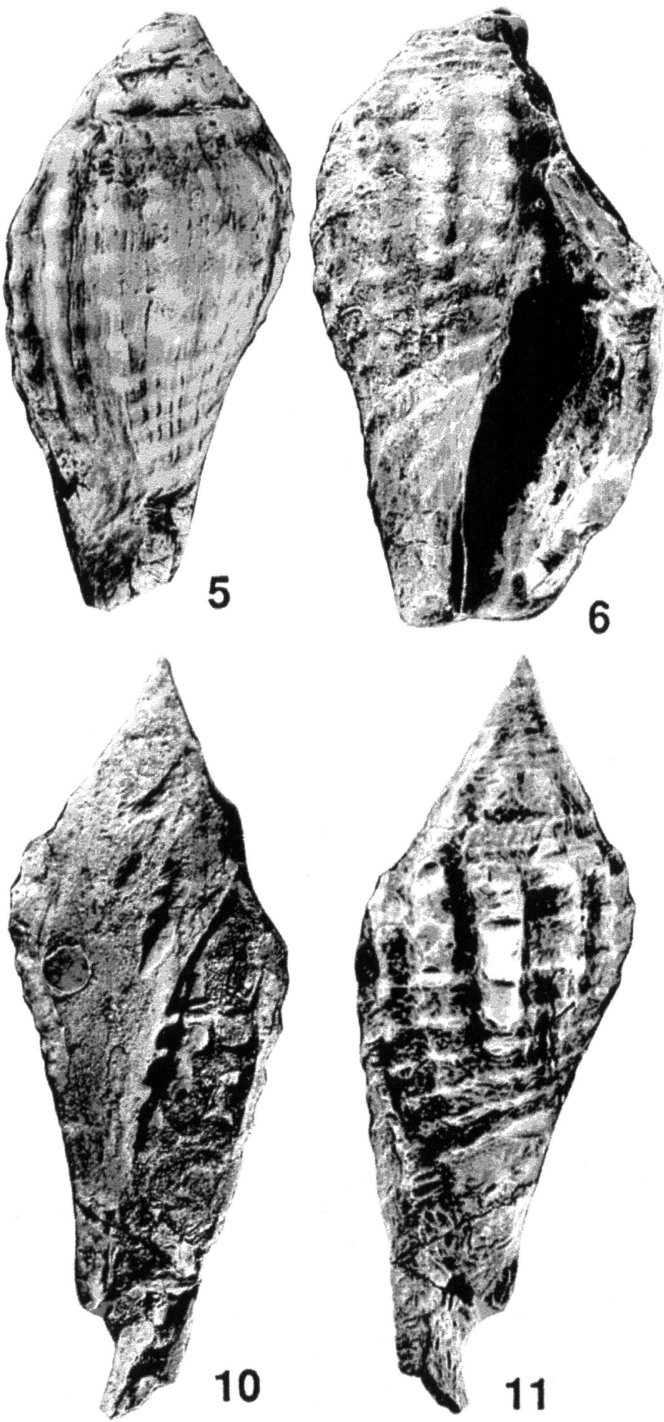

FIGURE 9-Volutoderma santana Packard, 1922 from the Pacific slope of North America. 1, 2, hypotype, LACMIP 13211, ×1.7; 3, hypotype, LACMIP 13210 , ×1.6; 4, 5, hypotype, LACMIP 13208, ×1.2; 6, 7, holotype, UCMP 12294, ×1; 8, 9, hypotype, LACMIP 13209, ×0.8; 10, 11, hypotype, LACMIP $12130, \times 0.8$.

from the Cenomanian at Gabel Dalta, Sinai, figured as Volutoderma sp. by Abbass (1963, p. 96, pl. 9, fig. 6, 6a), also have slightly concave whorl sides and are probably not Volutoderma.

Dartvelle and Brébion (1956) and Brébion (1956) referred poorly preserved specimens from Bas-Congo, Africa to Volutoderma cf. V. capensis (Woods, 1907) and V. cf. V. constricta Dall, 1907. Kiel and Bandel (2003) have referred Rostellites capensis Woods, 1907 from the Umzamba Formation (Santonian-Campanian, South Africa) to Liopeplum capensis. The Bas-Congo specimens are probably congeneric, i.e., Liopeplum Dall, 1890 rather than Volutoderma. Dall (1907, p. 8, fn 5) supplied the new name Volutoderma (Rostellana?) constricta for a specimen from the Pugnellus Sandstone of the Colorado Group, figured by Stanton (1893, pl. 34, fig. 3). Stanton's figure does not resemble those of Brébion (1956, pl. 1, fig. 10a, 10b) and Dartvelle and Brébion (1956, pl. 1, figs. 10, 11).

Bandel (2000) has referred two of Stoliczka's Indian volutes from near Garudamangalam in the Santonian Kulakkalnattam Formation to Volutoderma, figuring them as Volutoderma stoliczkana (Dall, 1907) and V. multistriata (Stoliczka, 1868). However, judging from Bandel's figures, these specimens lack three characteristics of Volutoderma: differentiated spiral sculpture, an apexward spread of the parietal callus shield, and a somewhat bulbous whorl shape. They are more similar to Carota than to Volutoderma.

Japanese Volutoderma (Rostellinda?) sp. Yabe and Nagao, 1925 (p. 123, pl. 29, fig. 13, 13a, 13b) from North Sakalin has shape, sculpture, and growth line suggestive of Carota. Volutoderma (Rostellinda)? sp. Yabe and Nagao, 1928 (p. 95, pl. 17, fig. 16, 16a) from Hokkaido, has only two columellar folds, but the specimen is too poor to suggest another assignment.

Kiel and Perrilliat (2004) figured (fig. 4. 10, 11) a 34 mm-high specimen as Volutoderma? sp. from the Maastrichtian Mexcala Formation, Guerrero, southern Mexico. It resembles juveniles of Pacific Slope Volutoderma spp., but this Mexican specimen lacks its anterior siphon and appears more biconic than any known $\mathrm{Pa}-$ cific Slope species.

Wenz (1943) raised several of Dall's (1907) taxa to generic rank and gave the range of Volutoderma as Senonian to Maastrichtian from North America and New Zealand, but only Pacific Slope of North America specimens ranging in age from Coniacian to early Maastrichtian age display characteristics of Volutoderma.

Of the eight Upper Cretaceous, Pacific Slope species Anderson (1958) referred to Volutoderma: three species-V. gabbi (White, 1889), V. californica Dall, 1907, and V. suciana Dall, 1907-are 

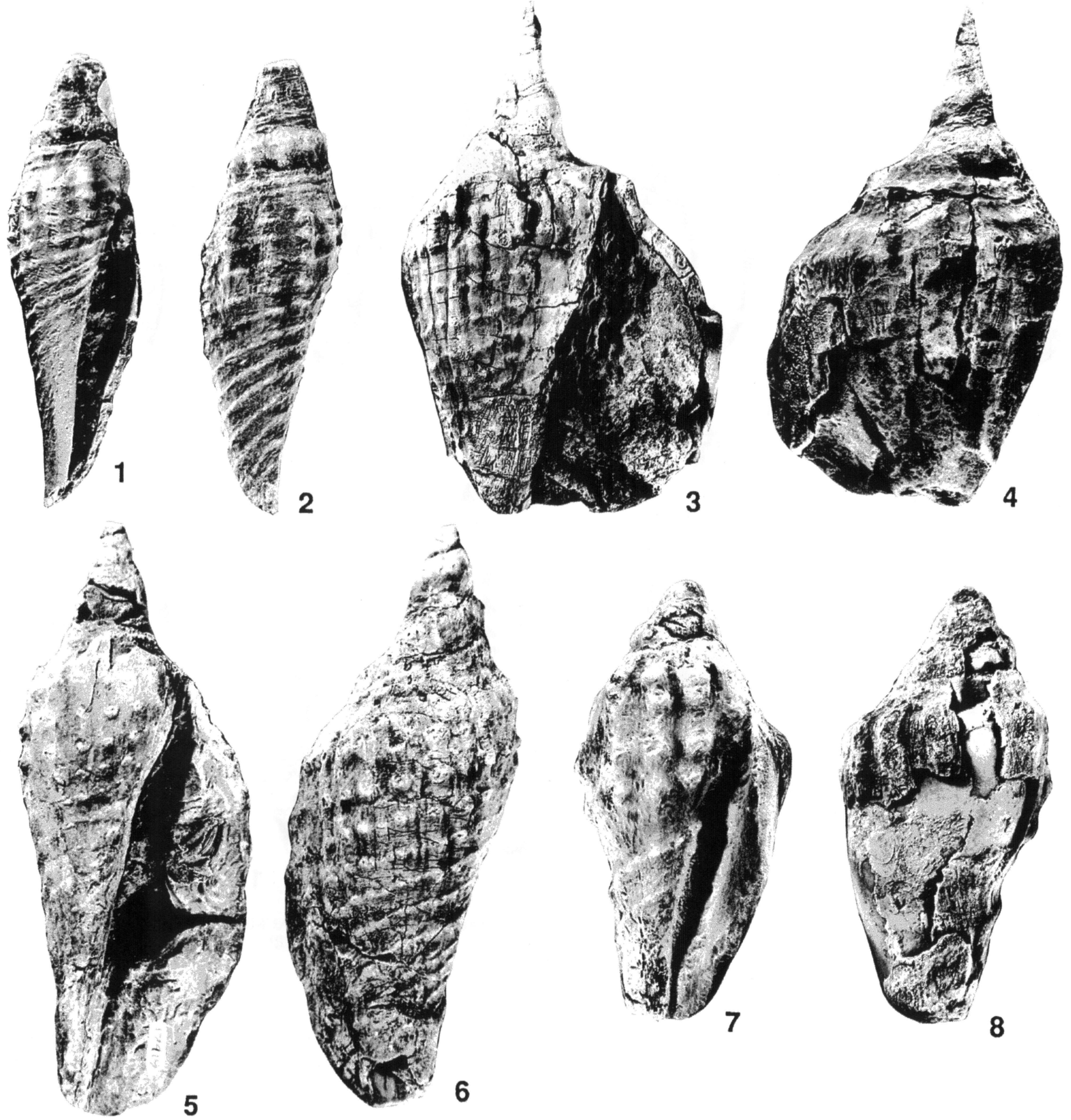

FiguRe 10-Volutoderma spp. from the Pacific slope of North America. 1-6, Volutoderma magna Packard, 1922; 1, 2, hypotype, LACMIP 13214, $\times 1.3$; 3, 4, hypotype, LACMIP 13212, ×0.69; 5, 6, hypotype, LACMIP 13213, ×0.71. 7, 8, Volutoderma? antherena $\mathrm{n}$. sp., holotype, LACMIP $13226, \times 0.85$.

junior synonyms of $V$. averillii; two species, $V$. santana Packard, 1922 and V. magna, are Volutoderma; and four species are not Volutoderma. Saul and Popenoe (1993) assigned Volutoderma mitraeformis $(\mathrm{Gabb}, 1869)$ and $V .(R$.) dilleri (White, 1889) to Carota, "Volutoderma" crossi Anderson, 1958 to the perissityid genus Cydas Saul and Popenoe, 1993, and "V." jacksonensis Anderson, 1958, to the fasciolariid genus Drilluta Wade, 1916.

Characteristics of Volutoderma include an elongate fusiform shell, a flat to concave sloping ramp, and, in several species, a slight shoulder. The spire is shorter than the aperture. The body whorl is large and is either basally slightly contracted or passes with gradual slope into a relatively long anterior canal that is generally twisted to the left. The inner lip is expanded onto the whorl face and forms a callus shield that, in most species, overlaps the previous suture, thus obscuring it. The outer lip (especially in mid-Campanian and younger species) commonly has an expanded rim to the lip edge. These barely flared lip-edges result in raised collabral ridges of variable prominence that are, perhaps, best preserved on the ramp and at the suture. Posterior to the sinus and the suture, a raised edge continues and joins the posterior extremity of the callus shield. These raised imbricate growth ridges give Volutoderma a corrugated subsutural collar similar to that of Longoconcha, but in Volutoderma, sculpture on spire whorls adjacent to the suture is obscured by deposits of the callus shield and the raised-growth ridges. The columella of Volutoderma, described as straight (e.g., Gabb, 1877; Dall, 1907; Sohl, 

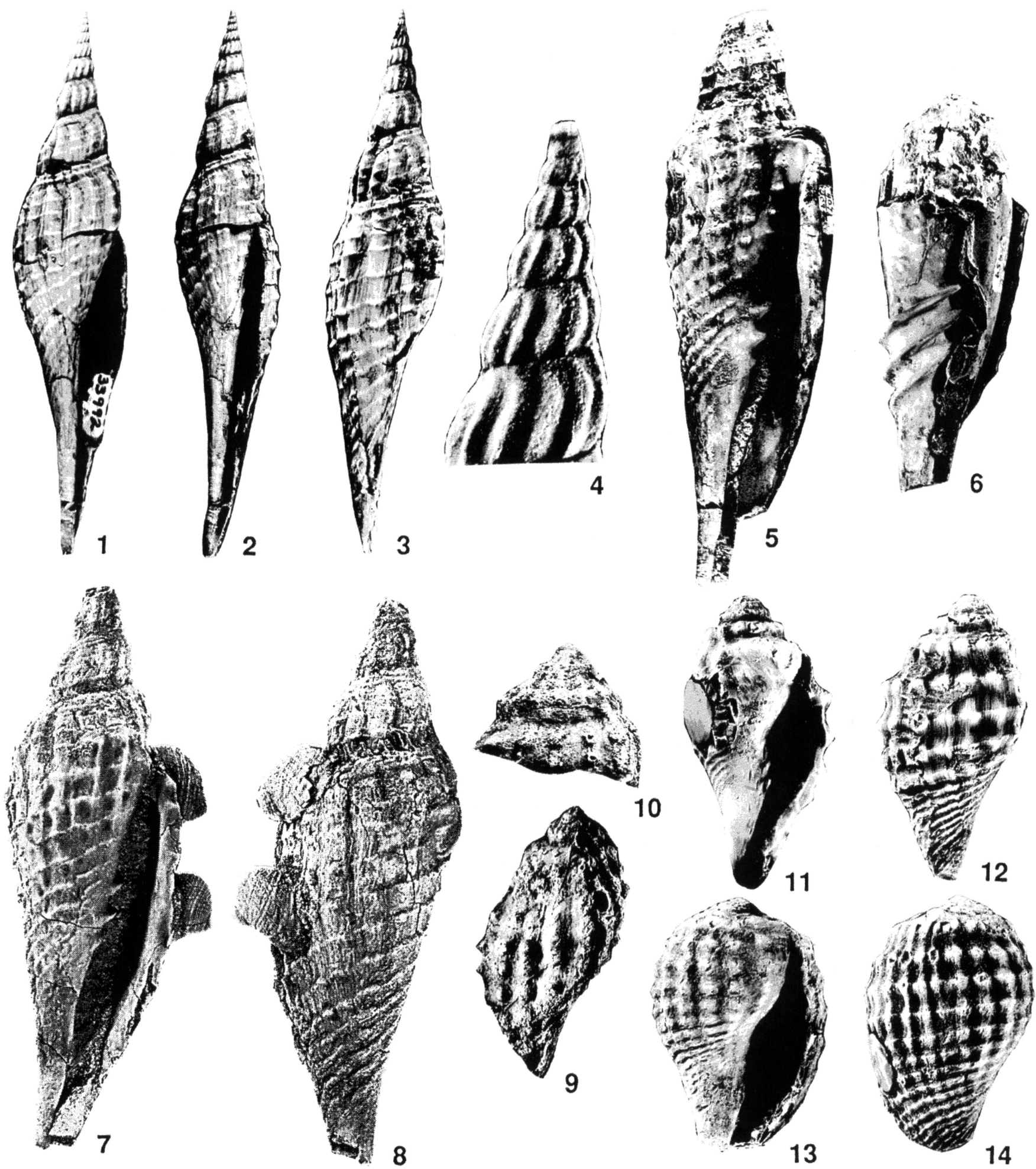

FigURE 11-Longoconcha and Retipirula from the Pacific slope of North America. 1-8, Longoconcha eumeka n. sp., 1-4, paratype, SDNHM 33992, 1-3,

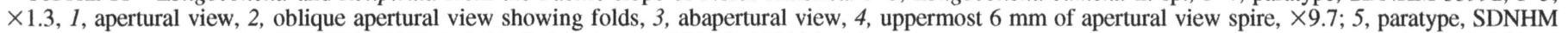
$70968, \times 0.66 ; 6$, paratype, SDNHM 25959, $\times 0.76 ; 7,8$, holotype, SDNHM 70974, $\times 0.75 .9$, 10, Retipirula calidula n. sp. rubber peels, 9, holotype LACMIP 13218, $\times 1.4$; 10, paratype, LACMIP 13219, ×1.6. 11, 12, Retipirula crassitesta (Gabb, 1869), ×1.7, hypotype LACMIP 13221, 11, apertural view, 12, back view. 13, 14, Retipirula pinguis n. sp., holotype LACMIP 13222, ×1.5 13, apertural view, 14, back view.

1964), is commonly arched anteriorly with three folds near midpoint of the aperture. In some species the folds are not visible from the aperture. Sculpture of juvenile whorls is strongly axial, becoming more strongly spiral, to the extent, in some species, of loss of axial ribs in adults. The species described herein average four (with individual variants having three to six) weaker spirals on the ramp, one or two stronger noded spirals at the shoulder position, two to ten widely spaced spirals across the body of the whorl, followed by several more closely spaced, unnoded, weaker spirals on the siphonal neck. 
The oldest Volutoderma of this study, V. querna of Coniacian age, in addition to its small protoconch, differs from modern volutes in having a growth-line sinus on the ramp. This sinus is positioned closer to the posterior suture than is that of Carota dilleri, but not at the posterior suture as in $V$. averillii. It is the sinus that Bandel (2003) has indicated requires the inclusion of Volutoderminae in Pyrifusidae Bandel and Dockery, 2001. Dall (1907) claimed that the posterior sinus of Volutoderma allowed for protrusion of part of the mantle. Whatever the function of the posterior outer lip sinus, early Late Cretaceous volutes display a migration of this sinus toward the posterior suture and away from its earlier more abapical position. First appearance of the genus Volutoderma is in the Coniacian.

During the Campanian, in the southern part of its range, $\mathrm{Vol}$ utoderma diversified and formed three morphological lineages. 1) "Typical" Volutoderma consists of Volutoderma querna n. sp., V. averillii (Gabb), V. blakei n. sp., V. jalama n. sp., and $V$. perissa $n$. sp. These species all have three strong, medially placed folds on the columella visible at the aperture. 2) "Angelica" includes $V$. angelica $\mathrm{n}$. sp., $V$. elderi n. sp., and $V$. ynezae $\mathrm{n}$. sp. which have three, more oblique, weaker folds on the columella that are not visible from the aperture. 3) "Magna" includes $V$. santana Packard, $V$. magna Packard, and $V$. ? antherena $\mathrm{n}$. sp. which have a vasiform shape with a nearly straight columella.

\section{SPECIES OF THE “TYPICAL" LINEAGE}

Diagnosis.-Volutoderma species with elongate fusiform shell, having three strong columellar folds visible from the aperture and both axial and spiral sculpture. Axial sculpture diminished in maturity but spirals noded on whorl face, unnoded on siphonal area.

\section{VOLUTODERMA QUERNA n. $\mathrm{sp}$. Figure 4.3-4.13}

Diagnosis.-Relatively short Volutoderma with nearly conical spire and growth line noticeably broadly sinused on ramp; early whorls with broad sloping ramp. Parietal shield not extending beyond suture of previous whorl, anterior sinus barely deflected to left.

Description.-Shell large, elongate fusiform with conical spire, spire about one third of height, pleural angle $40^{\circ}-45^{\circ}$, diameter about one third of height; early whorls with low collar at suture, slightly concave on ramp, without wellmarked shoulder, convexly inflated about periphery, contracted anteriorly, anterior siphon somewhat deflected to left (apertural view); ramp concavity filled by posteriorward extension of callus shield and crossed by raised traces of outer lip. Growth line with broad posterior sinus on ramp, prosocline across suture, joining parietal-shield extension without additional notch, and slightly convex across periphery of whorl. Sculpture of 12-17 moderately strong, rounded axials, best developed between ramp and anterior siphon, overridden by narrower spiral cords tending to form nodes at axials, spiral interspaces twice as wide as cords, two to six narrow cords on ramp, four to seven noded cords around periphery, six to nine unnoded anterior cords. Aperture elongate, ellipsoidal, sharply narrowed posteriorly; outer lip a little reflexed, especially posteriorly with broad notch in ramp; ramp crossed by strong imbricate growth lines that join posterior edge of parietal shield; columella rather straight with three strong, medially placed folds; inner lip with moderate callus shield extending posteriorly to subsutural collar.

Etymology. - Latin, querna, of oak for its occurrence along Oak Run, Shasta County, northern California.

Types.-Holotype LACMIP 13154 from LACMIP 24106, Clover Creek, Area 4, Santonian. Paratypes LACMIP 13155-13158 from LACMIP 10816 , Oak Run, Area 4, Coniacian; LACMIP 13159 from LACMIP 10821, Pine Timber Gulch, Area 4, late Coniacian; 13160-13163 from LACMIP 24106, Clover Creek, Area 4, Santonian; 13164 from LACMIP 10797, Clover Creek, Area 4, Santonian; LACMIP 13165 from LACMIP 23624, Chico Creek, Area 6, Santonian; 13166 from LACMIP 23633 Chico Creek, Area 6, Santonian.

Material examined--About 157 specimens; one specimen from LACMIP loc. 24672, Area 3; ninety-eight specimens, from Area 4, (twenty-four from Member IV, thirty-three from Member V, forty-one from Member VI); fiftyfour specimens from Area 6; six specimens from Area 9.

Occurrence.-Age range Coniacian to Santonian. (Area 3) Hornbrook Formation, Osburger Gulch Member; lower Coniacian. (Area 4) Redding Formation, Members IV and lower V, Coniacian; upper V and VI, Santonian.
(Area 6) Chico Creek; Chico Formation, Musty Buck Member, Santonian. (Area 9) ?basal Forbes Formation; upper Santonian.

Discussion.-The extension of the parietal shield beyond the posterior end of the aperture results in the covering of some sculpture and of the subsutural collar. The posterior extension of the shield fills the concavity of the ramp and gives the spire a nearly straight-sided profile. Extension of the outer lip leaves raised, irregularly spaced growth-line ridges crossing this callus- filled area at a small opisthocline angle to the shell axis.

Most specimens of $V$. querna are incomplete as to height; complete diameters are common. Most adult nearly complete specimens are between 70 and $80 \mathrm{~mm}$ in height and are, on average, a third smaller than mature $V$. averillii. Volutoderma querna paratype LACMIP 13159 from LACMIP 10821 is incomplete but has a diameter of approximately $52 \mathrm{~mm}$, nearly twice as great as that of the next largest specimen; and its postulated height would have been in excess of $150 \mathrm{~mm}$. The spire and ramp of the last whorl have been eroded away; three strong columellar folds are visible; the expanded part of the last whorl is well preserved with five widely spaced noded cords and perhaps two low unnoded cords. Shell of the final $30 \mathrm{~mm}$ of the whorl to the outer lip is thickened and has strong growth lines which nearly obliterate the spiral cords. An incomplete specimen from LACMIP loc. 10794 displays five columellar folds, but all other specimens of Volutoder$m a$ in which the folds are known have three.

Both strength of sculpture and number of cords and ribs are variable, but $V$. querna commonly has fewer, somewhat stronger axial ribs, a straighter sided, more conical spire, a more steeply sloping ramp, and less bend to the anterior siphon than does $V$. averillii. Volutoderma querna grades into $V$. averillii, and specimens of latest Santonian and earliest Campanian age, such as those from the Haslam Formation at Brannan Lake, are difficult to assign.

\section{VOLUTODERMA AVERILLII (Gabb, 1864) Figure 5}

Fusus averillii GABB, 1864, p. 83, pl. 18, fig. 34; J. C. MerriAm, 1895, p. 40.

Volutilithes navarroensis Shumard. GABB, 1864, p. 102, pl. 19, fig. 56. Not Volutilithes navarroensis Shumard, 1861, p. 192.

Volutilithes navarroensis Shum. ?. GABB, 1869, p. 120.

Volutoderma navarroensis GABB, 1877, p. 289 (type of the genus).

Fulguraria Navarroensis Shumard. WHITEAVES, 1879, p. 117, pl. 15, fig. 3, 3a; BOLTON, 1965, p. 21. Not Volutilithes navarroensis Shumard, 1861.

Fulguraria Gabbi WHITE, 1889, p. 23, pl. 3, fig. 1 [not. p. 46].

Rostellites gabbi (White). WhrTEAvEs, 1903, p. 356. Not Rostellites gabbi (White) of WARING, 1917, p. 68 , pl. 9 , fig. $8=$ Volutoderma blakei $\mathrm{n}$. $\mathrm{sp}$. Volutoderma californica DALL, 1907, p. 10, fn 1, new name for $V$. navarroensis Gabb not Shumard. ANDERSON, 1958, p. 173, pl. 52, fig. 1, 1a.

Volutoderma suciana DALL, 1907, p. 10, fn 4, new name for Fulguraria Navarroensis Whiteaves.

Volutoderma gabbi (White). ARNOLD, 1910, figure only, pl. 1, fig. 1 (reprint of White, 1889, pl. 3, fig. 1) not p. 11. Reprinted in ARNOLD AND ANDERsoN, 1910, figure only, pl. 23, fig. 1 (reprint of White, 1889), not p. 60 (figure reprinted as Volutoderma in FowKES, 1982, p. 15). ANDERSON, 1958, p. 174 in part "White's holotype"; not specimen from "Sidney Richardson farm" = Volutoderma blakei n. sp.

Volutoderma averillii (Gabb). STEWART, 1927, p. 409, pl. 22, fig. 10, 11; SCHENCK AND KEEN, 1940, p. 25, pl. 17, fig. 4 (reprint of Arnold, 1910, pl. 1, fig. 1); WeNZ, 1943, p. 1,312, fig. 3,736 (reprint of Stewart, 1927, pl. 22, figs. 10,11 ). SHIMER AND SHROCK, 1944, p. 508, pl. 209, fig. 21 (reprint of Gabb, 1864, fig. 56); ELDER AND SAUL, 1993, p. 184, pl. 2, fig. 21.

Longoconcha navarroensis (Shumard). LUDVIGSEN AND BEARD, 1994, p. 96 fig. 61. Reprinted LUDVIGSEN AND BEARD, 1997, p. 115, fig. 72. Not SHUMARD, 1861.

Diagnosis.-Volutoderma with large, very fusiform, shell tapering similarly both anteriorly and posteriorly from the periphery; early whorls with concave ramp and noticeable shoulder; longitudinal ribs fading on large individuals, growth line slightly notched at suture; parietal-callus shield extending posteriorly onto 
previous whorl and across face of last whorl; anterior siphon deflected to left.

Description.-Shell large, elongate fusiform with somewhat turriculate spire; spire near one third of height, pleural angle about $43^{\circ}$ in adult, near $20^{\circ}$ in juvenile, shell diameter about one third of height; early whorls with collared suture, concave ramp, and well developed shoulder, convexly inflated about the periphery, contracted anteriorly, anterior siphon deflected to left (apertural view). Growth line of some young specimens with shallow antispiral sinus on ramp, of large specimens without sinus and having slight posterior notch at the suture; slight reflection of outer lip resulting in raisedcollabral ridges near suture on ramp crossing onto previous whorl and joining posterior end of parietal shield. Sculpture of 12-17 moderately strong, rounded axials, best developed between ramp and anterior siphon, overridden by narrower spiral cords tending to form nodes at ribs; cord interspaces about three times width of cords, commonly two to five narrower cords on ramp, five to six noded cords about the periphery, six to eleven unnoded anterior cords. Aperture elongate ellipsoidal, sharply narrowed posteriorly, with posterior sinus at the suture; columella arched anteriorly with three strong medially placed folds; inner lip with callus shield extending posteriorly onto previous whorl and medially across face of last whorl.

Types.-Of Fusus averillii, holotype UCMP 11964, recognized by J. C. Merriam (1895), Tuscan Springs, on Little Salt Creek, Tehama County, northern California, Area 5, Chico Formation, early Campanian. Of Volutilithes navarroensis Gabb, 1864, not Shumard; lectotype ANSP 4298 (not 4299 as in Stewart, 1927, p. 409), (Stewart, pl. 22, fig. 11), paralectotype ANSP 4298a (pl. 22, fig. 10) designated by Stewart (1927), Area 5. Of Volutoderma californica Dall, 1907, new name for Volutilithes navarroensis Gabb, 1864, lectotype ANSP 4298 designated by Stewart (1927), Area 5.

Of Fulguraria Navarroensis Whiteaves, 1879, not Shumard; hypotypes GSC 5786, a-e, (Bolton, 1965, p. 21) Sucia Island, San Juan County, Washington, Area 2, lower Cedar District Formation, late early Campanian. Of Volutoderma suciana Dall, 1907, syntypes GSC 5786, a-c new name for Fulguraria Navarroensis Whiteaves, 1879, lectotype GSC 5786c, here designated (fide Bolton, 1965 figured by Whiteaves, 1879, pl. 15, fig. 3) measured by Dall (1907, p. 10, fn 4); paralectotypes GSC 5786, a-b, d-e (fide Bolton, 1965, GSC 5786 figured by Whiteaves, 1879, pl. 15, fig. 3a).

Of Fulguraria Gabbi White, 1889; lectotype USNM 20112 here designated, near Centerville, Butte Creek, Butte County, California, Area 6, Chico Formation, early early Campanian.

Of Volutoderma californica Dall (Anderson, 1958), hypotype CASG 10673 from CASG loc. 1125B, Tuscan Springs, Area 5, Chico Formation, early early Campanian.

Of Volutoderma averillii (Gabb, 1864) (Elder and Saul, 1993), hypotype LACMIP 12131 from LACMIP loc. 10865, Tuscan Springs, Area 5. Hypotypes this paper, UCR 3435/1 from near Pentz, Area 7; LACMIP 13168 and 13173 from LACMIP 10865 Tuscan Springs, Area 5; 13169, and 13170 from LACMIP 23648, Chico Creek, Area 6; 13271 and 13272 from LACMIP 24082 Tuscan Springs, Area 5; RBCM.EH2004.013.0001 from Nanaimo River Road at the Boulder Creek bridge, Area 1, Haslam Formation, early early Campanian.

Of Longoconcha navarroensis (Shumard), not Shumard, 1861, (Ludvigsen and Beard, 1994, 1997), hypotypes VIPM 053 and 054, from Brannan Lake, west of Nanaimo, Area 1, Haslam Formation, early Campanian.

Material examined.-About 168 specimens; thirteen from Area 1, twentyfive from Area 2, seventeen from AREA 5, seventy-seven from Area 6, one from Area 7, five from Area 16, Bell Canyon, twenty-eight from Area 18.

Occurrence.-Early Campanian, zones of Submortoniceras chicoense and Baculites chicoensis to Hoplitoplacenticeras vancouverense, Canadoceras newberryanum, and Baculites inornatus (see Fig. 2). (Area 1) Haslam, Pender and lower Cedar District Formations; lower Campanian. (Area 2) lower Cedar District Formation; upper lower Campanian. (Area 5) Chico Formation undifferentiated, lower Campanian. (Area 6) Chico Formation, in Butte Creek upper Musty Buck and Ten Mile Members; in Chico Creek, Ten Mile Member; lower lower Campanian. (Area 7) Chico Formation, Pentz Road Member; lower lower Campanian. (Area 16) Bell Canyon, Chatsworth Formation; upper lower Campanian. (Area 18) Ladd Formation, upper Holz Shale Member; lower Campanian.

Discussion.-Volutoderma averillii commonly reached a larger size than $V$. querna. The spire of $V$. averillii is more turriculate than that of $V$. querna or $V$. blakei. The anterior canal of $V$. averillii is also more strongly bent to the left, and the columella is more arched anteriorly. In mature specimens, the growth line of $V$. averillii is not sinused on the ramp but is notched at the suture. The parietal callus shield extends posteriorly beyond the previous suture and covers a broader area across the whorl than in $V$. querna n. sp.

Volutoderma averillii has spire whorls that are more convex and less slender than those of $V$. blakei, but mature $V$. blakei are larger and stockier than $V$. averillii. Nodular ends of the axial ribs of $V$. averillii are more visible on its spire whorls.

Several juvenile specimens of $V$. averillii from Chico Creek LACMIP loc. 23643 have very early whorls preserved. Shell material is, in most specimens, decalcified enough that the surface flakes away, thereby removing surface details. Two specimens appear to have at least partial protoconchs, which are low turbinate and of about two and one half whorls. The change from protoconch to teloconch is inferred to be at a diameter of $0.6-0.8$ $\mathrm{mm}$ where the well-rounded whorl profile alters to noticeably taller and straighter-sided and axial ribs become present. By the second or third juvenile whorl, the strong axial ribs are overridden by finer spirals, whose width is about that of the interspaces. At heights of less than $40 \mathrm{~mm}$, spirals are of nearly equal strength and undifferentiated into noded and unnoded (Fig. 5.1, 5.2). At a height of $40 \mathrm{~mm}$, shells are slenderly fusiform with strong axial and spiral sculpture in which interspaces are wider than ribs and cords. Strength of axial ribs is diminished at $80 \mathrm{~mm}$, but shells remain slender

Larger specimens of $V$. averillii expand in girth, and a robust specimen from the Chico Formation on Butte Creek "near Centerville" was named Fulguraria gabbi White, 1889. North of Centerville, the basal conglomerate of the Chico Formation, i.e., the Ponderosa Way Member, rests on pre-Cretaceous metamorphic rocks. Ammonites from localities south of Centerville, along Butte Creek, identified by Matsumoto (1960, p. 19), included $B$. chicoensis and $C$. newberryanum, which are indicative of the early Campanian. Other large, robust specimens of $V$. averillii sensu stricto (e.g., Fig. 5.13, 5.14 ), with which White's specimen is conspecific, are known from well-constrained early Campanian Chico Formation outcrops along Butte Creek (Area 6) and near Pentz (Area 7). Despite the imprecise locality and stratigraphic data for White's locality, his specimen is considered by us to be from the Baculites chicoensis Zone and of early Campanian age.

In contrast, Anderson (1958, p. 174) considered V. gabbi (White) similar to a specimen collected by S. Richardson from the Hornbrook Formation, Siskiyou County, northern California (CASG loc. $455 \mathrm{~A}=$ CASG 61798) and of early Senonian age because, according to Anderson, it was from "near Desmophyllites siskiyouensis $\mathrm{n}$. sp., Prionocycloceras crenulatum (Anderson, 1902) and above the level of Nowakites klamathonia n. sp." Anderson included in CASG loc. 455A specimens collected over time by several individuals, and Matsumoto $(1960$, p. 2, 3) noted that the fossils were derived from more than one stratigraphic interval, i. e., $P$. crenulatum and $N$. klamathonia (=Kossmaticeras fide Matsumoto, $1959 \mathrm{~b}$, p. 64) are of Coniacian age and from lower Hornbrook Formation. Whereas "D. siskiyouensis n. sp." = Desmophyllites dyphylloides (Forbes, 1846) is late Campanian (Matsumoto, 1959b, p. 10). With the assistance of J. DeMouthe, $\mathrm{S}$. Richardson's Hornbrook Volutoderma specimen was found in the CASG collection (CASG 61798.03). It is Volutoderma blakei and has in its matrix a small Metaplacenticeras pacificum. Both $M$. pacificum and $M$. californicum (Anderson, 1902) were described from upper Hornbrook strata now referred to as the Rancheria Gulch Sandstone of the Blue Gulch Mudstone Member (e.g., Nilsen, 1984a, 1984b). Its ammonites are indicative of early late Campanian age, an age in agreement with that of $D$. dyphylloides.

White's (1889, pl. 3, fig. 1) Volutoderma gabbi was reprinted by Arnold (1910), Arnold and Anderson (1910), and Fowkes (1982) to accompany discussions of specimens from the Joaquin Ridge Sandstone Member of the Panoche Formation (Area 11). Reports (Arnold, 1910; Arnold and Anderson, 1910) of $V$. gabbi and $V$. averillii from the Joaquin Ridge Sandstone Member are probably based on misidentifications. The Joaquin Ridge Sandstone overlies the Metaplacenticeras pacificum-bearing Alcalde Shale, and no undoubted $V$. averillii has been found from so 
young a horizon. North of Coalinga near Joaquin Ridge, the Uhalde Shale at CASG 2361 has yielded Volutoderma perissa $\mathrm{n}$. sp. Westward of Coalinga, specimens of $V$. blakei have been recovered from redeposited cobbles in conglomerate lenses within the Alcalde Shale.

Anderson (1958) argued that the type specimen of Fusus averillii was immature and could not be shown to be the same species as the much larger lectotype for Volutoderma californica. However, in support of Stewart's (1927) synonymizing, growth series from the Ten Mile Member of the Chico Formation on Chico Creek (e.g., LACMIP loc. 23643) indicate that Stewart was correct in considering $V$. navarroensis (Gabb), V. gabbi, and $V$. californica to be junior synonyms of $V$. averillii.

Dall (1907) thanked J. F. Whiteaves of the Geological Survey of Canada for the loan of original material for Fulguraria navarroensis Shumard in Whiteaves, 1879 (Whiteaves listed 10 specimens). Bolton (1965) listed six hypotypes, and five were loaned by the Geological Survey of Canada for this study. According to Bolton GSC 5786c, the tallest of these specimens, is Whiteaves' plate 15, figure 3 (i.e., Fig. 5.11, 5.12). Although Dall (1907) named these specimens Volutoderma suciana and referred to Whiteaves, 1879, plate 15, figure $3,3 \mathrm{a}$, he did not designate a type specimen for $V$. suciana. He considered it more closely related to $V$. gabbi than to $V$. californica, both of which we consider to be $V$. averillii. He differentiated $V$. suciana by its large size and lack of axial ribs from $V$. californica, not realizing that these are mature characteristics of the species.

\section{VOLUTODERMA BLAKEI new species Figure 6.1-6.4}

Rostellites gabbi (White). WARING, 1917, p. 68, pl. 9, fig. 8. Not Fulguraria Gabbi White, 1889 or Rostellites gabbi (White) of Whiteaves, 1903.

Volutoderma gabbi (White). ANDERSON, 1958, p. 174, in part (specimen found by S. Richardson); Not Fulguraria Gabbi White, 1889.

Diagnosis.-Large Volutoderma, shell slender in youth but with expanded penultimate and ultimate whorls; both spiral and axial sculpture at small and intermediate shell sizes, but primarily spiral cords at maturity; growth line sharply sinused at suture.

Description.-Shell large, elongate fusiform, slender in youth becoming stout as adult; spire high, near one third of shell height; suture just anterior to shoulder; pleural angle $32^{\circ}$; diameter of shell less than one third of height; early whorls with steeply sloping ramp and noticeable shoulder, shoulder becoming effaced and marked only by sculpture; ultimate whorl with enlarged diameter; anterior siphonal neck long, gently flexed. Growth line sharply sinused at suture, nearly straight across the body whorl. Early whorls with strong axial ribs; spirals present by diameter of $4 \mathrm{~mm}$; next whorl with four spirals on well-defined steep ramp and two spirals overriding posterior ends of eight to ten axial ribs forming shoulder; about seven to nine wide-spaced, noded spirals on body whorl; unnoded, more closely spaced spirals on siphonal neck. Aperture elliptical, long, and narrow, with narrow posterior sinus at suture anterior sinus long, open; columella with three folds visible from aperture; inner lip callused, callus shield extending posteriorly to shoulder.

Etymology:-The species is named for William Blake, a member of the original California Geological Survey.

Types.-Holotype LACMIP 13174 from LACMIP 22415, Bee Canyon, Lomas de Santiago, Area 18. Paratypes LACMIP 13175 from LACMIP 8186, Aliso-Santiago Creek divide, Area 18; LACMIP 13176 from LACMIP 10105 Aliso-Santiago Creek divide, Area 18; LACMIP 13177 from LACMIP 26471 Cooper Canyon, Area 11; LACMIP 13178 from LACMIP 22415, Bee Canyon, Area 18; LACMIP 13359 and 13177 from LACMIP 17829, Bee Canyon, Area 18; CASG GeTy 10760 from CASG 61798.03 near Montague, Area 3: CASG 68821.01 from CASG 68821 Dayton Canyon, Area 16.

Material examined.-About 84 specimens; one from CASG loc. 61798 Area 3; two from Cooper Canyon cobble in conglomerate, Area 11 (a cast in sandstone may also be this species); nine from Area 16; one from Area 17; forty-three from Area 18, (one from Schulz Ranch Conglomerate Member, forty-two from Pleasants Sandstone Member).

Occurrence.-Early middle to early late Campanian, zones of Hoplitoplacenticeras? bowersi and Metaplacenticeras pacificum. (Area 3) Hornbrook Formation, Blue Gulch Mudstone Member, Rancheria Gulch Sandstone beds; lower upper Campanian. (Area 11) Panoche Formation, cobble in Alcalde Member; middle Campanian. (Area 16) Chatsworth Formation; middle Campanian. (Area 17) Tuna Canyon Formation; lower upper Campanian. (Area
18) Williams Formation, Schulz Ranch Conglomerate Member, middle Campanian, and Pleasants Sandstone Member, lower upper Campanian.

Discussion.-The wide steep ramp of $V$. blakei gives its early whorls a more straight-sided aspect, whereas the concave ramp and strong shoulder nodes make early whorls of $V$. averillii more turriculate. Volutoderma blakei has a larger number of noded spirals over the whorl periphery than do $V$. averillii or $V$. querna. Volutoderma averillii has a more strongly flexed anterior canal than does $V$. blakei. Several specimens of $V$. blakei with a diameter of over $70 \mathrm{~mm}$ are from LACMIP loc. 22415, but none has both a complete spire and anterior siphon. A probable height for LACMIP 13174 with a diameter of $73 \mathrm{~mm}$, estimated by adding spire height and siphonal length from two other specimens, would be about $206 \mathrm{~mm}$.

Volutoderma blakei occurs with Hoplitoplacenticeras? bowersi and with Metaplacenticeras pacificum in southern California. Recognition of $V$. blakei with $M$. pacificum in the Blue Gulch Mudstone Member of the Hornbrook Formation near Montague, northern California, is discussed under $V$. averillii. Although most specimens from the lower Cedar District Formation on Sucia Island are $V$. averillii, some have taller spires than typical $V$. $a v$ erillii and reduced shoulder development similar to V. blakei (see CASG 228.06).

\section{VOLUTODERMA JALAMA new species Figure 6.5-6.13}

Volutoderma sp. cf. V. averillii (Gabb, 1864). DAILEY AND POPENOE, 1966, fig. 3 .

Diagnosis.-Volutoderma with relatively short, strongly sculptured shell; spire narrowly tapered with concave profile, whorl abruptly widened at maturity to much wider adult pleural angle. Posterior sinus strongly V-shaped, creating raised strong spiral track at suture.

Description.-Shell moderately large, plumply fusiform, almost biconic in youth becoming roundly stout as adult; spire near one third of shell height: suture just anterior to shoulder; juvenile pleural angle $37^{\circ}$, adult pleural angle $50^{\circ}-60^{\circ}$; maximum diameter of shell near one third of height; early whorls with steeply sloping ramp, shoulder marked mainly by change in sculpture; ultimate whorl with enlarged diameter. Growth line sharply V-sinused at suture, nearly straight across side of whorl. Both axial and spiral sculpture relatively strong; axial ribs persistent on utimate whorl; three spiral cordlets on ramp, about five to seven wide-spaced noded spiral cords on whorl; unnoded, more closely spaced spirals on siphonal neck; 13-16 axial ribs strong at shoulder fading toward siphonal neck. Track of V-shaped posterior notch leaving a strong spiral at suture. Aperture elliptical; columella with three folds visible from aperture; inner lip callused, parietal callus shield extending posteriorly to shoulder.

Etymology.-Named for Jalama Creek, Santa Barbara County, California.

Types.-Holotype LACMIP 13179 from LACMIP 6243. Paratypes LACMIP 13180 from LACMIP 6242; LACMIP 13181 from LACMIP 10695 LACMIP 13182 from LACMIP 10701; LACMIP 13183 from LACMIP 24120; LACMIP 13184 from LACMIP 24144. All localities in Area 15.

Material examined.-Twenty-one specimens from Area 15 and one poorly preserved specimen from Area 12 (LACMIP loc. 24183).

Occurrence.-Late late Campanian, zone of Baculites rex. (Area 15) Jalama Formation. (Area 12) Panoche Formation.

Discussion.-Volutoderma jalama is very similar to $V$. blakei $\mathrm{n}$. sp. but differs from the latter in being relatively stouter for its height, having stronger, rougher-appearing sculpture, a deeper, very $V$-shaped posterior siphonal notch that forms a strong weltlike cord along the suture (Fig. 6.12), and in having succeeding whorls envelop more of the previous whorl. The sharp, narrow spire of $V$. jalama does not have the steep sutural slope of the $V$. angelica group but has a sutural slope more similar to that of $V$. perissa n. sp.

\section{VOLUTODERMA PERISSA n. $\mathrm{sp}$.} Figure 7.1-7.4

? Volutoderma cf. magna Packard. ANDERson AND HANNA, 1935, p. 26. Volutoderma cf. V. californica Dall. SUNDBERG AND RINEY, 1984, fig. 3.8. Volutoderma sp. cf. V. magna Packard. ELDER, SAUL, AND POWELL, 1998, p. 160 , pl. 1 , fig. 11 . 
Diagnosis.-Elongate, relatively narrow whorled Volutoderma, shell lacking shoulder angulation and having aciculate spire. Axial sculpture consisting mainly of aligned nodes on cords.

Description.-Shell large, elongate ovoid with aciculate spire; spire profile concave; ramp demarcated by closer spacing of four weaker cords; body whorl unshouldered; pleural angle of aciculate spire $22^{\circ}$, of mature spire about $45^{\circ}$; diameter near one third height of shell; anterior siphon very moderately flexed. Growth line strongly notched at suture. Sculpture of weak axial costae, expressed mainly by aligned nodes on cords; about eight noded, widely spaced, narrow cords on last whorl, and five or more unnoded cords on siphonal neck. Aperture elongate, ellipsoidal, widest near base of penultimate whorl; columella with three strong folds visible from aperture, just adapical to widest part of aperture; inner lip callused, pallial callus shield covering and extending beyond apertural face of body whorl, posteriorly covering suture and apertural face of penultimate whorl.

Etymology-Greek, perissos, odd, strange.

Types.-Holotype SDNHM 33994 from SDNHM 3405, Area 19. Paratypes CASG 2361.07 from 2361, Area 11; LACMIP 13185 and LACMIP 13186 from LACMIP 2855, Area 19; LACMIP 13187 and LACMIP 13188 from LACMIP 23268, Area 19; LACMIP 13189 from LACMIP 27136, Area 20; SDNHM 25968 from SDNHM 3162, Area 19; SDNHM 33993 and SDNHM 70972 from SDNHM 3405, Area 19. Hypotype UCMP 39906 from USGS M8830, Area 8.

Material examined.-Thirty-two specimens; one from Area 8, Anchor Bay; two from Area 11, Joaquin Ridge, north of Coalinga; one from Area 16, "Lang Ranch," west end Simi Hills; two from Area 19, Carlsbad Research Center; one from Area 20, Punta Banda; two from Area 21, near San Antonio del Mar; twelve from Area 22, one from Cañon San Fernando, eleven from Arroyo Santa Catarina.

Occurrence--Late Campanian/Early Maastrichtian, commonly in association with Baculites lomaensis. (Area 8) Gualala Formation, Anchor Bay Member. (Area 11) Panoche Formation, Uhalde Shale Member. (Area 16) "Lang Ranch," west end Simi Hills, upper Chatsworth Formation. (Area 19) Point Loma Formation. (Area 21) and (Area 22) Rosario Formation.

Discussion.-Volutoderma perissa resembles other "Typical" Volutoderma in having three strong columellar folds that are clearly visible within the aperture, although the most anterior fold extends forward less than the other two. Volutoderma perissa differs from the other "Typical" species in its aciculate spire, convex ramp rounding into the whorl side without an angulate shoulder, and more enveloping mature whorls. Its spire is most similar to that of $V$. jalama but is more aciculate.

A protoconch is not preserved on the studied specimens. The earliest whorl preserved on SDNHM 33993 has a diameter of 1 $\mathrm{mm}$; diameter of its fifth whorl is $5 \mathrm{~mm}$; of its eighth whorl is $15 \mathrm{~mm}$; height of these eight whorls is $24.5 \mathrm{~mm}$. Sculpture on the early whorls appears to have been covered by callus deposits.

Identification of incomplete specimen UCMP 39906 is somewhat questionable, and its locality USGS M8830, Area 8, Gualala Formation at Anchor Bay is the most northern locality known for this species. Otherwise the most northern locality for Volutoderma perissa is at CASG loc. 2361, Area 11, the type locality of Baculites lomaensis Anderson, northwest of Coalinga, Fresno County, California.

Arnold (1910, p. 11, pl. 1; in Arnold and Anderson, 1910, p. 60, pl. 23) listed Volutoderma gabbi (White) from his "loc. 3" northwest of Coalinga, Area 11 . As noted earlier, the figure is a reprint of White's 1889 Volutoderma gabbi $=V$. averillii from Butte Creek. Included on Arnold's plate with the Volutoderma are three misidentified bivalves which were also from "loc. 3," northwest of Coalinga: "Mactra ashburneri Gabb, 1864" = Cymbophora triangulata (Waring, 1917), "Meekia sella Gabb, 1864" = Meekia (Mygallia) daileyi Saul and Popenoe, 1962, and "Tellina? ooides Gabb, 1864" = Willimactra (Petromactra) truncata (Gabb, 1864). These bivalves indicate a younger age than that of $V$. averillii. All three bivalves occur in the Jalama Formation (Saul and Popenoe, 1962; Saul, 1973, 1974), which has yielded V. jalama $\mathrm{n}$. sp. The bivalves are also present in the Rosario Formation of Baja California associated with $V$. perissa n. sp., which occurs in the Uhalde Shale Member of the Panoche Formation north of Coalinga, Fresno County.
Anderson and Hanna (1935) reported two imperfect specimens of Volutoderma cf. V. magna from near Santa Catarina Landing, but available specimens from the Rosario Formation near Santa Catarina Landing are either L. eumeka n. sp. or V. perissa.

SPECIES OF THE “ANGELICA" LINEAGE

Diagnosis.-Volutoderma species having ovoid, greatly enlarged last whorl; high, narrow spire with steep sutural slope; and three, oblique columellar folds not visible from aperture; sculpture dominantly spiral; axial sculpture reduced in maturity, becoming nearly obsolete in some.

\section{VOLUTODERMA ANGELICA new species}

Figure 8.1, 8.2

Diagnosis.-Large Volutoderma with high, pointed spire and roundly expanded adult whorls; early whorls weakly sculptured, expanding slowly with steep sutural slope; parietal callus shield thick, expanded roundly over face of last whorl.

Description--Shell large, fusiform, round-shouldered, with ramp delimited only by sculpture; spire high, narrow with steep sutural slope, and rounded whorl profiles, spire height about one fifth of shell height; pleural angle $23^{\circ}$. Penultimate and ultimate whorls enlarged, roundly expanded posteriorly and contracted anteriorly; diameter of shell about one third of height. Growth line with strong notch at suture; reflection of outer lip results in raised collabral ridges near suture on ramp crossing onto previous whorl and joining posterior end of parietal shield. Sculpture of about 16 broad, weak, rounded axial costae overridden by widely spaced, narrow spiral cords, spiral cords forming elongate nodes at intersections with axials on strongly sculptured specimens; ramp defined by finer, up to five, close-spaced cords and absence of axials. Aperture elongate, expanded medially; columella somewhat arched anteriorly, callused, with three, medially placed, oblique folds, not visible from the aperture; parietal shield very thick, spreading roundly over face of last whorl and expanded posteriorly to suture. Outer lip reflected, especially posteriorly, lip extended adapically to notch-like posterior sinus, and forming thickened right edge of shield.

Etymology--Named for Los Angeles, Latin, angelicus, angelic.

Types--Holotype LACMIP 13190. Paratypes LACMIP 13191-13193; LACMIP 13194-13196. All types from LACMIP 10715 = LACMIP 6965, Dayton Canyon, Area 16.

Material examined.-About thirty-five specimens; thirty-one from Area 16, Dayton Canyon; four questionably identified specimens from (Area 18) Santa Ana Mountains (two from upper Holz Shale; two from Schultz Conglomerate).

Occurrence.-Early early? Campanian to early middle Campanian, associated with Hoplitoplacenticeras? bowersi Anderson, 1958, Baculites cf. B. inornatus Meek, 1862 (Matsumoto, 1960) and B. anceps pacificus Matsumoto and Obata, 1963 (Saul and Alderson, 1981) in Dayton Canyon. (Area 16) lower Chatsworth Formation; lower middle Campanian. (Area 18) questionbly identified specimens upper Holz Shale Member, Ladd Formation, lower Campanian; partial specimens, Williams Formation, Schulz Ranch Conglomerate Member; ?lower middle Campanian).

Discussion.-Volutoderma angelica resembles $V$. magna in having a narrow but high spire with steep sutural slope and rapidly enlarging penultimate and ultimate whorls, but none of the specimens from Dayton Canyon develops the ascending, callusbordered, U-shaped posterior sinus or the expanded and enveloping outerlip of $V$. magna. Additionally, specimens of $V$. angelica have a more rounded body whorl and a columella that is arched anteriorly. The early whorls of $V$. angelica have a more convex profile and commonly show three noded cords. Sculpture is best preserved on paratype 13194. A few poorly preserved specimens from the uppermost Holz Shale (e.g., Area 18, LACMIP loc. 10723) resemble $V$. angelica in having a convex profile and three noded cords on early whorls but do not have as steep a sutural slope as $V$. angelica from Dayton Canyon.

Volutoderma angelica is most similar to V. elderi $\mathrm{n}$. sp., which is more weakly sculptured, has fewer, more widely spaced spiral cords, and nearly lacks axial costae and nodes on the spirals.

At Dayton Canyon, $V$. angelica occurs with ammonites previously identified as Metaplacenticeras californicum (?) (Anderson, 1902 ) or M. pacificum and M. sanctamonicae Waring, 1917 (Popenoe, 1954). As pointed out to us by J. M Alderson, the most 
abundant Dayton Canyon ammonite is Metaplacenticeras? bowersi Anderson, 1958 (type locality Dayton Canyon) which Matsumoto (1984) referred to Hoplitoplacenticeras? bowersi (Anderson, 1958). Dayton Canyon outcrops yield both V. blakei $\mathrm{n}$. sp. and $V$. angelica, but $V$. angelica is far more common.

Schoellhamer et al., (1981) listed two specimens from the Schulz Ranch Conglomerate Member of the Williams Formation (LACMIP loc. $15900=$ SA66 $=$ F43 of Schoellhamer et al., 1981) as Volutoderma santana. They do not have the strong sculpture, shouldered whorls or wide ramp cords of $V$. santana, but have instead sculpture, whorl shape, and steep sutural slope more similar to $V$. angelica, and suggest a correlation of the Schulz Ranch Conglomerate Member with the Chatsworth Formation of Dayton Canyon.

\section{VOLUTODERMA ELDERI new species}

Figure 8.3-8.7

Diagnosis.-Large, round-shouldered Volutoderma sculptured by widely spaced, narrow cords and having high, narrow spire with very steep sutural slope.

Description.-Shell large, fusiform, round-shouldered, with ramp delimited only by sculpture; spire high, narrow, with steep sutural slope, and roundedwhorl profile; spire height about one third of shell height; pleural angle without penultimate whorl $23^{\circ}$, with penultimate $38^{\circ}$. Penultimate and ultimate whorls enlarged, roundly expanded posteriorly, and contracted anteriorly; diameter of shell about one third of height. Growth line with strong notch at suture. Sculpture of three to four weak cords on ramp (may be effaced), nine to twelve widely spaced, narrow spiral cords, commonly unnoded on last whorl; interspaces four to six times width of cords; axial ribs weak, present in juveniles, lost on mature shells. Aperture elongate, expanded medially; columella barely arched anteriorly, callused, with three, medially placed, oblique folds not visible from aperture (Fig. 8.6); parietal shield roundly expanded, thin over face of whorl, thick near posterior end of aperture, thickest adapical to aperture. Outer lip thin, deeply sinused at suture.

Etymology--Named for W. P. Elder, whose work on a Cretaceous PacificSlope time scale was very helpful.

Type specimens.-Holotype LACMIP 13197 from LACMIP 10120, Santiago-Aliso Canyon divide, Area 18. Paratypes LACMIP 13198-13200 from LACMIP 10105, Area 18; LACMIP 13201 from LACMIP 8186, Area 18; LACMIP 13202 from LACMIP 21530, Area 18; LACMIP 13203 from LACMIP 24207, Area 18; LACMIP 13358 from LACMIP 17828, Area 18.

Material examined.-At least twenty-nine specimens; one partial specimen from Area 16, head of Dayton Canyon; one poorly preserved specimen from Area 17; twenty-seven partial specimens from Area 18.

Occurrence.-Late middle to early late Campanian, Metaplacenticeras pacificum Zone. (Area 16) Chatsworth Formation; late middle Campanian. (Area 17) Tuna Canyon Formation; early late Campanian. (Area 18) Williams Formation, Pleasants Sandstone Member; early late Campanian.

Discussion.-Juveniles of $V$. elderi are very tall and slender. Early whorls up to a diameter of about $9 \mathrm{~mm}$ have axial ribs, but these fade on the following two whorls. The ultimate whorl of the most complete specimen, LACMIP 13358 , is flattened, making measurement of diameter impossible. A diameter of $22 \mathrm{~mm}$, measured on its relatively uncrushed penultimate whorl, is too low as the greatest diameter of that whorl was doubtless within the area crushed. Anterior siphonal areas and the outer lip are missing from all available specimens. Outer lip of paratype LACMIP 13358 has been broken back far enough to expose the columellar folds (Fig. 8.6). Volutoderma elderi is very similar to $V$. angelica $\mathrm{n}$. sp. from which it differs in having a less distinctly marked ramp that is somewhat more sloping than in $V$. angelica, and spirals that are more widely spaced and weakly noded to the extent of being unnoded on the ultimate whorl. Volutoderma elderi resembles $V$. ynezae n. sp. in lacking nodes on the spirals when mature but differs in having fewer more widely spaced spirals and in lacking the subangulate shoulder of $V$. ynezae.

\section{VOLUTODERMA YNEZAE new species}

Figure 8.8-8.11

Volutoderma magna? PACKARD, 1922. DaIleY AND PoPENOE, 1966, figs. 2 and 3 , listed only.
Diagnosis.-Volutoderma with an aciculate spire, strong, rounded shoulder, 16-17 spiral cords, and no axial ribs on mature whorls. Columellar folds not visible from aperture.

Description.-Shell large, almost strombiform; spire high, narrow with steep sutural slope, pleural angle not measured, maximum diameter of shell near shoulder; early whorls not available; last whorl roundly inflated, slightly angular at shoulder, wrapping posteriorly, and enveloping previous whorl; suture of body whorl climbing on last half whorl to previous suture at aperture; ramp flatly sloping, nearly smooth, complete anterior siphon not available. Growth line strongly notched at suture, relatively straight across whorl. Sculpture on adult of 16-17 narrow spiral cords with wider interspaces, interspaces two or three times width of cords. Aperture made wide by expansion of last whorl; columella arched anteriorly; inner lip heavily callused, wrapping onto back of siphonal neck anteriorly; outer lip forming deep U-shaped notch at suture; parietal shield apparently thin, expanded roundly over apertural face of last whorl.

Etymology--Named for the Santa Ynez Mountains.

Types.- Holotype LACMIP 13204 from LACMIP 10690, Jalama Creek, Area 15. Paratypes LACMIP 13205 from LACMIP 10690, Area 15; LACMIP 13206 from LACMIP 24118, Area 15; LACMIP 13207 from 24128, Area 15.

Material examined.-Eighteen specimens from Area 15.

Occurrence.-Late late Campanian, Baculites rex Zone. (Area 15) Jalama Formation.

Discussion.-As in V. magna, V. elderi n. sp., and V. angelica n. sp., the columellar folds of $V$. ynezae are deep within the aperture and out of sight. The profile of $V$. ynezae is similar to that of $V$. magna in developing a shoulder but is more roundly expanded anterior to the shoulder, giving $V$. ynezae the appearance of being less tall. None of the $V$. ynezae specimens has as widely expanded a final whorl as $V$. magna, and all $V$. ynezae have a more arched columella. The columella of $V$. ynezae is also more strongly arched than that of $V$. elderi. Volutoderma ynezae has less axial sculpture on its mature whorl than any of the other volutes discussed in this paper. Some specimens of $V$. ynezae have no axial ribs or nodes on less-than-mature whorls. Spiral cords on $V$. ynezae are commonly more numerous and closer together than cords on $V$. angelica and $V$. elderi.

The pleural angle of the immature whorls of $V$. ynezae appears to be have been narrow and the spire apparently had a steeply sloping sutural angle, but all available specimens of $V$. ynezae have broken spires and retain barely more than the mature whorls, which provide a wide pleural angle.

Submature specimens of $V$. ynezae resemble $V$. perissa in blimplike shape and perhaps an aciculate spire, but $V$. ynezae is less elongate, has spirals that are closer together and less noded, and has weaker columellar folds that are not visible from the aperture.

A submature specimen, from LACMIP 24118, which had not yet developed a shoulder, has a thin parietal shield roundly expanded over the apertural face of its last whorl. The posterior suture of its last whorl has climbed toward the previous suture but not up to it; despite the specimen's immaturity, a strong callus is present at the posterior siphonal notch. The spiral cords of this specimen are faintly noded.

\section{SPECIES OF THE "MAGNA" LINEAGE}

Diagnosis.-Strongly sculptured Volutoderma that tend to be vasiform with a relatively straight columella; two strongly noded cords on the shoulder, and two? to eight more anterior, strongly noded cords; growth line strongly notched on ramp; three columellar folds present but not all visible from aperture.

\section{VOLUTODERMA SANTANA Packard, 1922 Figure 9}

Volutoderma santana PACKARD, 1922, p. 432, pl. 36, fig. 3; ANDERSON, 1958, p. 175; EldER AND SAUL, 1993, p. 184, pl. 2, fig. 20.

Diagnosis.-A relatively short-spired almost pyriform Volutoderma with shouldered whorls and strongly noded sculpture, unnoded cords on ramp wider than interspaces. Anterior canal long, curved to left. Columella with three folds, two visible at aperture. 
Description.-Shell medium-sized, subpyriform, height near two and one half times diameter, with turriculate spire about one fourth of shell height, pleural angle $53^{\circ}$, early whorls with collar at suture, whorl concave on ramp with well-marked shoulder, whorl convexly inflated about periphery, adult whorls contracted anteriorly, anterior siphon somewhat deflected to left (apertural view). Growth line notched at suture, barely notched prosoclinally across ramp and nearly straight to siphonal tip. Sculpture of about 9-12 widely spaced, strong, short, rounded ribs per whorl; ribs best developed just anterior to shoulder, overridden by strong spiral cords forming nodes at intersections with ribs; commonly two strongest cords just anterior to shoulder, four to five noded cords anterior to shoulder cords; about four unnoded spirals on siphonal neck, ramp with two to four weaker unnoded spirals, posterior two or three of which being as wide as interspaces; cords at nodes about equal in width to interspaces. Aperture elongate, ellipsoidal, narrowed posteriorly with notch at suture; columella slightly arched anteriorly with two of three strong, medially positioned folds visible within aperture; inner lip with moderate callus shield extending posteriorly to suture.

Type specimens.-Holotype UCMP 12294 from UCMP 2135 , Area 18. Hypotypes LACMIP 12130 from LACMIP 26467, Area 10; LACMIP 13208 from LACMIP 10084; LACMIP 13209 from LACMIP 10080; LACMIP 13210 from LACMIP 10093; and LACMIP 13211 from LACMIP 15904, Area 18.

Material examined.-Eighty specimens: one from Area 10, north of Pigeon Point; seventy-seven from Area 18, Santa Ana Mountains. Questionably identified two: one from Area 16, Dayton Canyon, and one from Area 18, Williams Formation, Schulz Ranch Conglomerate Member.

Occurrence.-Early Campanian and possibly early middle Campanan. (Area 10) Pigeon Point Formation; lower or lower middle Campanian. (Area 16) lower Chatsworth Formation, lower middle Campanian. (Area 18) Ladd Formation, upper Holz Shale Member; lower Campanian; and possibly Williams Formation, Schulz Ranch Congomerate Member; lower middle Campanian.

Discussion.-Packard's (1922) referral of the holotype of $V$. santana to the "Turritella pescaderoensis zone" is evidently an error. Popenoe $(1937,1942)$ showed that species of Packard's "Turritella pescaderoensis zone" came from the Williams Formation, Pleasants Sandstone Member, of middle to early late Campanian age, but Popenoe (1942) identified as V. santana specimens from the upper Holz Shale Member of the Ladd Formation. No examples of $V$. santana are known from the Pleasants Sandstone Member. Matsumoto (1960, p. 143) listed Baculites $\mathrm{cf}$. $B$. inornatus Meek, 1862 from UCMP loc. 2135, the type locality of $V$. santana, and recognized $B$. inornatus from three uppermost Holz Shale localities. Packard's holotype of $V$. santana lacks spire and anterior canal, but its shoulder strength and type of sculpture, especially on the ramp, identify it with the more than 70 specimens from the upper Holz Shale here identified as V. santana.

Three specimens from the Schulz Ranch Conglomerate Member of the Williams Formation LACMIP locs. 15900 and 15904 were listed in Schoellhamer et al. (1981) as V. santana. However, the two specimens from LACMIP loc. 15900, although very incomplete, have more characteristics of $V$. angelica $n$. sp. than of $V$. santana. Volutoderma angelica has otherwise only been found in the Chatsworth Formation in strata yielding Hoplitoplacenticeras? bowersi (see Fig. 2). A mangled Chatsworth Formation specimen from LACMIP 10715 has nodes like those of $V$. santana. Possible co-occurrence of these two volutes, if correctly identified, gives $V$. santana a range into the early middle Campanian and an early middle Campanian age for the Schulz Ranch Conglomerate.

Volutoderma santana has a more southern distribution than $V$. averillii, whose range extends from British Columbia (Fig. 1) south to Orange County, California (Fig. 3). The northernmost occurrence of $V$. santana is in the southern sequence of the Pigeon Point Formation (Elder and Saul, 1993, pl. 2, fig. 20; this paper, Figs. 1, 3, Area 10).

Juvenile specimens of $V$. santana have the broadest apex of any Volutoderma considered here. Juveniles of $V$. santana are readily distinguished from juveniles of $V$. averillii, V. querna, $V$. angelica, and $V$. magna by having strong shoulder nodes, very short axial costae with wide interspaces, and a low spire with a wider pleural angle than these other species. Mature $V$. santana has larger nodes and fewer costae per whorl than V. averillii, $V$. querna $\mathrm{n}$. sp., and $V$. angelica. It is most similar to submature $V$. magna in sculpture and whorl shape, but lacks the expanded development of the ultimate whorl of mature $V$. magna. The ramp sculpture of $V$. santana differs from other Volutoderma in consisting of cords that are wider than their interspaces.

\section{VolưTODERMA MAGNA Packard, 1922}

Figure 10.1-10.6

Volutoderma magna PACKARD, 1922, p. 432, pl. 37, fig. 1; ANDERSON, 1958, p. 175.

Volutoderma magna (?) PACKARD, 1922, p. 432, pl. 38.

Not Volutoderma sp. cf. V. magna Packard. EL.DER, SAUL, AND POWELL, 1998 , p. 160 , pl. 1, fig. $11=V$. perissa n. sp.

Probably not Volutoderma $\mathrm{cf}$. magna Packard. ANDERson AND HANNA, 1935, p. 26.

Diagnosis.-Volutoderma with large strombiform shell, widely expanded outer lip, growth line strongly notched at suture, posterior notch defined by thick, vertical, U-shaped callus; spire high, pointed, with slender whorls and steep sutural slope; columella straight and heavily callused.

Description.-Shell large, strombiform (Packard, 1922, pl. 38), with greatest diameter at posterior part of whorl; adult whorls subshouldered with steeply sloping, slightly concave ramp rising to collar at suture; spire high, pointed, with slender, weakly sculptured, unshouldered whorls, and steep sutural slope: spire height less than a quarter of shell height; pleural angle about $35^{\circ}$, pleural angle of young specimens $27^{\circ}$. Penepenultimate and penultimate whorls expanded posteriorly to form rounded shoulder, penultimate and ultimate whorls enlarged, ultimate whorl enveloping penultimate whorl; diameter of shell about one half of height; anterior siphon somewhat deffected to left (apertural view). Growth line with strong, callused, U-shaped posterior notch at suture; slight reflection of outer lip resulting in raised collabral ridges near suture on ramp, crossing onto previous whorl, and joining posterior end of parietal shield. Sculpture of 17-18 commonly weak axial ribs overridden by 8-11 widely spaced, spiral cords forming nodes at intersections with costae, ramp with four weak cords, siphonal neck with at least four cords. Aperture elongate, widely expanded in maturity, columella rather straight, heavily callused, with three moderately oblique, medially placed folds, deep within aperture; parietal shield spreading over face of last whorl and expanded posteriorly onto previous whorl.

Types.-Holotype UCMP 12274 from UCMP 2166, Area 18. Hypotypes UCMP 12278 from UCMP 2166, Area 18; LACMIP 13212 from LACMIP 15901, Area 18; LACMIP 13213 from LACMIP 17419, Area 17; LACMIP 13214 from LACMIP 10096, Area 18

Material examined.--Twenty-four specimens; twelve from Area 18; twelve from Area 17.

Occurrence.-Late middle to early late Campanian, Metaplacenticeras pacificum Zone. (Area 17) Tuna Canyon Formation, upper middle Campanian; (Area 18) Williams Formation, Pleasants Sandstone Member, lower upper Campanian.

Discussion.-Packard (1922) hesitated to include the specimen that was larger and nearly devoid of shell, UCMP 12278, in V. magna, but it is a more mature example of the species in which the last whorl has wrapped over the moderately shouldered penultimate whorl, leaving one of the slender spire whorls exposed. Volutoderma magna resembles $V$. angelica $\mathrm{n}$. sp. in having a high slender spire with a steep sutural angle but differs from $V$. angelica in developing a vertical U-shaped gutter at the posterior end of the aperture, in having a straighter more heavily callused columella, in having more strongly noded spiral cords, and in having the whorl's periphery more posteriorly placed.

The overall aspect of the shell of $V$. magna with its high-pointed spire, very widely expanded outer lip, and posterior expansion of the whorl diameter, which narrows anteriorly without much flexure to the anterior siphon, is somewhat like a very elongate top. These are the largest volutes in the Santa Ana Mountains. Although Packard (1922) noted the prominent shoulder of $V$. magna as a characteristic distinguishing $V$. magna from " $V$. gab$b i$," the spire whorls of $V$. magna are not shouldered, nor is the last whorl. The penepenultimate and penultimate whorls expand posteriorly, forming a rounded shoulder, as in the holotype of $V$. 
magna, but the final whorl wraps over the penultimate whorl and produces an unshouldered profile.

Anderson (1958) questioned the Campanian age of $V$. magna, but $V$. magna is associated in both Area 18, the Santa Ana Mountains, and Area 17, the Santa Monica Mountains with Metaplacenticeras pacificum, an ammonite indicative of late middle to early late Campanian age (Fig. 2). Also Anapachydiscus californicus (Yabe in Yabe and Shimizu, 1921) [= Pachydiscus (Parapachydiscus) fascicostatum californicum Yabe], which was described from UCMP 2166, the type locality of $V$. magna, is Campanian (Matsumoto, 1960).

Specimens listed by Dailey and Popenoe (1966) as V. magna are $V$. ynezae n. sp. Anderson and Hanna (1935) referred two "imperfect specimens" of Volutoderma from near Santa Catarina Landing, Baja California, to "Volutoderma cf. magna Packard," but specimens from near Santa Catarina examined for this study are the new species Volutoderma perissa and Longoconcha eumeka.

\section{VOLUTODERMA? ANTHERENA new species}

Figure 10.7, 10.8

Diagnosis.-Vasiform volute with four strong spiral cords heavily noded at intersections with broad axial costae; shell slightly constricted just posterior to columellar folds; siphonal area with noded cord anterior to constriction. Spire conical. Growth line with notch at suture, prosocert across the ramp, sinused at the posterior row of nodes, and relatively straight toward the anterior sinus.

Description.-Shell moderately large, vasiform, basally contracted; whorl broadest at shoulder; spire short, pleural angle $73^{\circ}$; anterior siphon broken, extant part straight. Growth line with strong U-shaped notch at suture, projected to form antisinus on ramp, looped into sinus across shoulder nodes, projected into minor antisinus, and nearly straight across whorl side. Suture collared, suture waved by attachment anteriorly to second noded spiral of shoulder. Sculpture of 12 short, strong axial costae extending from shoulder to fourth strong spiral cord; spiral cords narrower than axial costae, bearing large nodes at intersections with costae; spirals one and two closely spaced at shoulder, making double node at shoulder; spirals two, three, and four widely spaced; interspace between fourth cord and fifth cord broad, three times width of third interspace, with narrow sunken spiral band adjacent to fifth cord; fifth cord narrower and more finely noded than previous four cords, aligned with posterior fold of columella; fifth interspace about four times width of fifth cord; sixth cord half as wide as fifth, ?unnoded. Aperture elongate, medially broadened; columella straight with two barely visible columellar folds posterior to the midpoint; inner lip lightly callused; parietal callus roundly expanded over face of ultimate whorl, but not overlapping suture, extending adapically to first row of shoulder nodes.

Etymology.-Greek, antherene, wild bee, for Bee Canyon.

Type.-Holotype, an incomplete specimen LACMIP 13226 from LACMIP 8182 , area 18.

Occurrence-Early late Campanian, Metaplacenticeras pacificum Zone with Baculites rex. One specimen, (Area 18) Williams Formation, Pleasants Sandstone Member.

Discussion.-The species is based on an incomplete specimen missing its early whorls, the end of the anterior siphon, and the outer lip. Surface preservation is poor; traces of fine spirals are not clear enough to describe; the nodes are worn; greatest diameter might be at either the shoulder or the third spiral cord. This singular specimen resembles $V$. santana in having a double row of nodes at the shoulder, but $V$. ? antherena is stouter with a stronger shoulder, has stronger sculpture with fewer axials and spirals. It resembles $V$. magna in having an apparently straight columella.

The species is questionably assigned to Volutoderma because there is no apparent expansion of the parietal callus apexward across the suture, and thus no corrugated subsutural deposit along the suture as in all other species of Volutoderma and in Longoconcha. Absence of the subsutural deposits may result from poor preservation. The growth line of $V$. ? antherena differs from that of Volutoderma in having, in addition to a sinus adjacent to the suture, an antisinus and a second shallow sinus at the second spiral cord.

\section{VOLUTODERMA? new species}

Figure $7.5,7.6$

Description.-Shell medium-sized, fusiform?, consisting of five or six round-shouldered whorls, spire short, suture on second row of nodes, one row of nodes showing on penultimate whorl, steep subsutural collar with two spirals at suture followed by narrow concave ramp. Pleural angle about $55^{\circ}$. Sculpture of at least 12 rounded costae and narrower spiral cords forming strong nodes at intersections, subsutural collar with two weakly noded cords, five to six strongly noded cords over inflated part of whorl, weaker cords on siphonal area. Aperture elongate, parietal shield roundly expanded on face of last whorl.

Type--Hypotype LACMIP 13217 from LACMIP loc. 30141.

Occurrence.-Early late Maastrichtian. One small specimen, Area 13, LACMIP loc. 30141, Bee Rock Road, about a mile north of Nacimiento River, San Luis Obispo County, California; El Piojo Formation.

Discussion.-The specimen is small, incomplete, somewhat post-depositionally flattened, and has about six whorls, the last one with about five noded spirals. Distortion has doubtless made the diameter measurement of $30.5 \mathrm{~mm}$ uncharacteristically large. At least one fold can be discerned on the columella. The anterior siphon is broken off, and the specimen is too incomplete to serve as a holotype. One noded spiral cord shows on the penultimate spire whorl adapical to the suture. Two cords are at the suture on the subsutural collar, but Volutoderma? has a concave ramp that was probably without cords. Absence of ramp cords is more typical of Retipirula than of Volutoderma, but the slightly elongated whorl shape is more similar to Volutoderma. A larger, more mature, more complete specimen of this species might make its referral to a genus more positive. Taliaferro (1944) listed Volutoderma averilli from his Asuncion Formation on the north side of the Nacimiento River. Unfortunately, no specimen bearing any resemblance to $V$. averillii, Volutoderma?, or Retipirula from the Asuncion Formation was found in the UCMP or the CAS collections. Coralliochama sp. was collected from the El Piojo Formation at UCMP A-3435.

Volutoderma? is less elongate and has more convexly rounded early whorls, and a less aciculate, shorter spire, than $V$. perissa $\mathrm{n}$. sp. Volutoderma? differs from Retipirula calidula n. sp. in having a relatively narrower, higher spire, a less roundly inflated body whorl, a less concave ramp, fewer costae on the last whorl, and weaker nodes on the subsutural collar. Whereas the whorl periphery of Volutoderma? is nearer the strong cord bounding the abapical margin of the ramp, the periphery of $R$. calidula is more abapically placed near the second strong cord from the ramp.

Volutoderma? occurs with Turritella chaneyi C. W. Merriam, 1941, and T. webbi paynei Saul, 1983, whereas Retipirula calidula $\mathrm{n}$. sp. occurs with $T$. chaneyi orienda Saul, 1983 and $T$. webbi Saul, 1983.

\section{Genus LONGOCONCHA Stephenson, 1941}

Type species.-By original designation Volutoderma tennesseensis Wade, 1926; Tennessee, Ripley Formation, Late Campanian.

Diagnosis.-Elongate, narrowly fusiform to subcylindrical volutodermine volutes, having flanks of mature whorls flattened, spire high and evenly tapering. Three or more strong columellar folds.

Occurrence--Late Cretaceous, Coniacian to Maastrichtian; North America: Atlantic and Gulf Coast of the United States; Europe: Germany and France; North Africa (Sohl, 1964); ?India (?Volutoderma of Bandel, 2000); southern California and northern Baja California, Mexico (herein).

Discussion.-The Texas species, Volutilithes navarroensis, was placed by Stephenson (1941) in Longoconcha, which he defined as a new subgenus of Volutoderma, differing from Volutoderma in being markedly more slender, having the flanks of the mature whorls conspicuously more flattened, and the ultimate whorl less constricted anteriorly. Stevenson designated Volutoderma tennesseensis, as type species and included V. navarroensis, Volutoderma protracta Dall, 1907, and Volutoderma (Longoconcha) dalli Stephenson, 1941 in Longoconcha. 
Sohl (1964) listed species of Longoconcha, eight from Gulf and Atlantic states and two from Europe and Africa. All of his listed species are Campanian and Maastrichtian, but he mentioned an undescribed Coniacian species from the Eutaw Formation of Alabama. He considered Longoconcha to be generically distinct from Volutoderma, and in so doing reduced the geographic range of Volutoderma to the eastern Pacific. We concur with Sohl in considering Volutoderma to be endemic to the eastern Pacific.

In addition to its elongate, slim, subcylindrical shell with an evenly tapering spire, and very elongate, rather flat-sided whorls, Longoconcha commonly has spiral cords that are not noded and some species have secondary as well as primary spiral sculpture on the body whorl. Some features considered characteristic of Longoconcha by Sohl (1964), a slender spire, axial ribs present on spire but absent on the mature whorls, and spiral cords not noded on mature whorls, are variously present in Pacific Slope Volutoderma species. The characters currently considered diagnostic of Volutoderma, a corrugated subsutural collar, strong, raised imbricate growth lines, a heavy inner lip callus, and a spreading parietal callus shield are based on better preserved material not then available to Sohl. Only one Pacific slope species, Longoconcha eumeka n. sp., is here included in Longoconcha.

\section{LONGOCONCHA EUMEKA new species}

Figure 11.1-11.8

? Volutoderma cf. magna Packard. ANDERSON AND HANNA, 1935, p. 26.

Diagnosis.-Strongly sculptured Longoconcha with well-developed, rounded shoulders. Spire scaliform, penultimate whorl with three or four strong spiral cords exposed posterior to suture.

Description.-Shell elongate fusiform to subcylindrical with high turriculate spire and rather flat-sided adult whorls; ratio diameter to height nearly one to four; anterior siphon barely? deflected to left; ramp crossed by raised traces of outer lip, forming U-shaped posterior notch as it joins parietal shield. Spire less than one third of shell height; pleural angle of young specimen $30^{\circ}$, of mature specimen $39^{\circ}$. Protoconch (?) of two and a half whorls, turbinate, diameter $0.4 \mathrm{~mm}$, ?smooth. Growth line with $U$-shaped sinus at suture becoming nearly vertical across body of whorl, turning slightly opisthocline? on the siphonal area. Mature sculpture of about 14 round-topped axial costae, weak across ramp, strongest at fifth to sixth spiral and becoming weak at eleventh to twelfth spiral, lacking or nearly so on siphonal area. Immature sculpture of spire whorls three to eleven: whorls three to six with strong arcuate (?collabral) costae and only faint indications of spirals; whorl seven with weak spirals; whorl eight with strongest spiral near midwhorl; whorl 11 with fourth and/or fifth spiral from suture strong, spirals one and two forming low collar, spiral three weak, spirals five or six to eleven or twelve forming nodes over axials, five or six weaker spirals on siphonal area. Aperture elongate, slightly wider posteriorly; outer lip edge denticulated at spiral cords, reflected to form narrow rim, extended posteriorly to form U-shaped trough extending above suture and joining parietal callus. Columella straight, callused, with three strong folds; parietal shield expanded over about two thirds of face of body whorl and extending posteriorly beyond aperture, in some specimens as far as suture.

Etymology-Greek, eumekes, of good length.

Types.-Holotype SDNHM 70974 from SDNHM 3405. Paratypes SDNHM 25952 from SDNHM 3162-L; SDNHM 33992 from SDNHM 3405; SDNHM 70968 from SDNHM 4071; SDNHM 25959 from SDNHM 3162C; LACMIP 13215 from LACMIP 23268; LACMIP 13216 from LACMIP 5991.

Material examined.-Fifty-seven specimens; one specimen from Area 11 upper Panoche Formation near Coalinga; three specimens from Area 16, at "Lang Ranch"; fifteen specimens from Area 19; two specimens from Area 21; thirty-six specimens from Area 22 (one from Cañon San Fernando, thirtyfive from Arroyo Santa Catarina).

Occurrence.-Late late Campanian to early Maastrichtian, zones of Baculites lomaensis, Baculites occidentalis, and Pachydiscus catarinae. (Area 11) type locality of Baculites lomaensis Panoche Formation, "Ragged Valley Shale" = Uhalde Shale Member; lower Maastrichtian. (Area 16) upper Chatsworth Formation. (Area 19) Point Loma Formation. (Areas 21 and 22) Rosario Formation. (Areas 16, 18, 19, 21, and 22) are upper upper Campanian?/ lower Maastrichtian.

Discussion.-Although this species has a high spire, its suture is not descending as in V. angelica n. sp., V. magna, and V. ynezae n. sp., nor is the spire as aciculate as that of $V$. perissa n. sp.
Early whorls of $L$. eumeka have predominantly strong axial sculpture without the overriding spirals common on species of Volutoderma. Axial sculpture is dominant on about six juvenile whorls of $V$. averillii, but dominant on 11 of $L$. eumeka. Volutoderma blakei $\mathrm{n}$. sp. and $V$. elderi n. sp. also have fewer juvenile whorls with dominantly axial sculpture than $L$. eumeka. Longoconcha eumeka resembles Gulf Coast species of the genus in shape and mature sculpture, but neither Stephenson (1941) nor Sohl (1964) mentioned such early sculpture on Longoconcha species, and their illustrations do not enlarge the early whorls to show details. Longoconcha eumeka has a greater height to diameter ratio than any Pacific slope Volutoderma. In general aspect, $L$. eumeka is more similar to the Gulf Coast species of Longoconcha than to Volutoderma and is more similar to the type species $L$. tennesseensis than to $L$. navarroensis largely because of the strength of the sculpture. Longoconcha eumeka differs from $L$. tennesseensis in commonly having more costae per whorl and in having them more persistent on mature specimens. On L. eumeka, secondary cords are generally not developed between the primary cords of the ultimate whorl. Longoconcha dalli Stephenson, 1941, Navarro Formation, Kemp Clay, Texas, L. protracta Dall, 1907, Ripley Formation, Alabama, and L. quadrilirata (Sohl, 1964) Ripley Formation, Mississippi, also lack secondaries. On some specimens of L. eumeka the ultimate whorl is "fimbriated" by remains of reflexed outer lip edges, which obscure the normal sculpture.

Longoconcha eumeka has been found over a greater geographical range than other species described herein, with the exception of $V$. averillii. Longoconcha eumeka is also fairly common in some areas. That it has not previously been described may result from the poor preservation of many of the specimens. In collections, $L$. eumeka has commonly been misidentified as a Volutoderma, and if assigned to a species, assigned either to $V$. averillii or V. magna.

\section{Genus RETIPIRULA Dall, 1907}

Type species.-Turbinella crassitesta Gabb, 1869 (p. 157, pl. 26 , fig. 37) by original designation Dall, 1907, p. 5, fn 2. Gabb's specimens were from "near Martinez," Contra Costa County, northern California.

Diagnosis.-Pyriform volutes with axial and spiral ribbing forming nodes at their intersections and having two to four columellar plaits. Aperture extended posteriorly into rounded posterior notch at suture; inner lip callus expanded, forming parietal shield on whorl face extending adapically over previous suture. Protoconch turbinate.

Occurrence.-Lake County, northern California to Baja California, Mexico; latest Cretaceous and early late Paleocene.

Discussion.-Retipirula was considered to be a subgenus of Volutocorbis Dall, 1890, by Wenz (1943) and Zinsmeister (1977), but the more U-shaped posterior notch of the aperture, the deposits extending posteriorly onto the previous whorl and obscuring the suture and part of the previous whorl, and the parietal shield are suggestive of a relationship to Volutoderma rather than to Volutocorbis. Additionally, the anterior sinus of Retipirula is flexed leftward (apertural view), but the sinus of Volutocorbis is essentially straight. The size difference between the strongly noded spiral cords of the whorl face and the finer smoother cords of the siphonal area is more distinct in Retipirula than in Volutoderma or in Volutocorbis, in both of which the change from coarse to fine is more gradational. Retipirula lacks the spiral cordlets commonly present on the ramp of Volutoderma.

Stewart (1927) chose a lectotype for the type species of Retipirula from among Gabb's three incomplete specimens at the Academy of Natural Sciences Philadelphia. Gabb's figure is a synthetograph, and as can be seen by comparison with Figure 11.11 and 11.12 and Zinsmeister's illustration (1977, p. 178, textfig. 1d), Gabb drew a more posteriorly sharply ovoid aperture rather than the somewhat rounder, posteriorly more broadly 
notched, and more heavily callused aperture of Retipirula. Gabb's specimens came from "near Martinez," and subsequent specimens from that vicinity have been collected from the lower Vine Hill Formation below the occurrence of P4 Zone foraminifers (C. E. Weaver, 1953, chart, p. 28-29). Occurrences of $R$. crassitesta in the Santa Susana Formation of the Simi Hills, Ventura County, California, are also in lower Selandian strata below those yielding foraminifera of the P4 Zone.

With recognition of $R$. calidula $\mathrm{n}$. sp. and $R$. pinguis $\mathrm{n}$. $\mathrm{sp}$,, Retipirula is no longer a monotypic genus. Its range is extended to include the youngest Cretaceous.

\section{RETIPIRULA CALIDULA new species \\ Figure $11.9,11.10$}

Diagnosis.-Relatively high-spired Retipirula with cords on siphonal area only slightly smaller than those of whorl face.

Description.-Shell medium-sized, pyriform, consisting of about five roundly expanded whorls, diameter to height ratio about 2.4 ; spire short with two rows of nodes on each whorl; suture on second row of nodes; ramp steep, concave. Pleural angle about $70^{\circ}$. Sculpture of about 12 rounded axial ribs and narrower spiral cords forming strong nodes at intersections; subsutural collar strongly noded; ramp without cords, five to six strongly noded cords over inflated part of whorl, weaker cords on siphonal area. Aperture elongate; outer lip forming U-shaped notch at suture, covering suture, and extending to posterior noded spiral of previous whorl, parietal shield roundly expanded on face of ultimate whorl. Columella with at least two folds.

Etymology:-Latin, calidula, warm, referring to Warm Springs Mountain.

Types--Holotype LACMIP 13218 and paratypes 13219, 13220 from LACMIP loc. 21591.

Material examined.-Three specimens from LACMIP loc. 21591.

Occurrence.-Latest Maastrichtian. (Area 14) Warm Springs Mountain, basal San Francisquito Formation.

Discussion.-Available specimens of $R$. calidula are all crushed and consist of molds or casts, but the following differences between $R$. calidula and $R$. crassitesta (Fig. 11.11, 11.12) are apparent. Retipirula calidula is larger with one more strong, noded spiral cord about the body whorl, has a wider ramp and a higher spire, the whorls of which show one additional noded spiral. On the spire of $R$. calidula the suture is noticeably anterior to the most posterior of the strong spirals causing a tabulation, but on the spire of $R$. crassitesta the suture is closely adjacent to the second noded cord of the previous whorl. Perhaps because of its larger size and higher spire this new species bears a greater resemblance to Volutoderma than does $R$. crassitesta.

At its type locality on Warm Springs Mountain, Retipirula calidula occurs with Turritella webbi and Turritella chaneyi orienda (Fig. 2).

\section{RETIPIRULA CRASSITESTA (Gabb, 1869)}

Figure $11.11,11.12$

Turbinella crassitesta GABB, 1869, p. 157, pl. 26, fig. 37.

Retipirula crassitesta (Gabb, 1869), DALL, 1907, p. 50; WARING, 1917, p. 83 pl. 13, figs. 1, 2; NELSON, 1925, p. 432, pl. 59, fig. 6a, 6b; STEwART, 1927 , p. 406, pl. 25, fig. 11; ClarK, 1929, pl. 2, fig. 10 (reprint of Nelson, 1925). Volutocorbis (Retipirula) crassitesta (GABB, 1869). WENZ, 1943, fig. 3,749 (reprint of Stewart, 1927). ZinSMEISTER, 1977, p. 177, text-fig. 1, a-d. Zinsmeister AND PARedes-Mejia, 1988, pl. 2, fig. 6.

Diagnosis.-Medium-sized, pyriform shell with moderately elevated, tabulated spire. Whorls roundly inflated with sculpture of six to seven spiral cords strongly noded at intersections with collabral costae; distinctly finer unnoded cords on siphonal neck.

Description.-Shell medium-sized, pyriform; spire moderately elevated, tabulated by ramp; ramp slightly concave, barely sloping, bordered distally by noded cord; whorl side roundly inflated, periphery at third to fourth noded cord, roundly constricted to broad siphonal neck; suture at second noded cord of previous volution; growth line opisthocline across ramp to first row of nodes, barely flexed across whorl flank. Sculpture of spiral cords and collabral costae, narrower than interspaces, six to seven cords, strong and sharply noded at intersections with costae; up to 10 finer unnoded cords on siphonal neck; costae weaker than cords, extending from first row of nodes to fifth or sixth row. Aperture elongate, widest medially, with slight posterior notch and moderate width anterior canal; outer lip evenly curved; inner lip callused with parietal callus expanded adapically up to first cord of previous whorl; three oblique columellar folds near base of columella, two nearly equal, moderately strong, and adapically one much weaker fold.

\section{Types.-Hypotype LACMIP 13221 from LACMIP 22307.}

Type locality.- "Martinez," Contra Costa County, California.

Material examined.-More than 200 specimens from the lower Santa Susana Formation, Simi Valley and Simi Hills, Area 16, Ventura County, California.

Occurrence.-Late early and early late Paleocene. Clear Lake, Lake County, "Martinez," Paleocene. Vicinity of Martinez, Contra Costa County, lower Vine Hill Formation; upper lower Paleocene. Rock Creek, Valyermo area, Los Angeles County, San Francisquito Formation; upper lower Paleocene. (Area 14) San Francisquito Formation; lower Paleocene. (Area 16) Santa Susana Formation; upper lower Paleocene. (Area 17) Santa Susana Formation; upper lower Paleocene. (Area 22) south of Arroyo Santa Catarina (LACMIP loc. 26364), Sepultura Formation; upper lower Paleocene.

Discussion.-As noted by Zinsmeister (1977), R. crassitesta resembles Volutocorbis virginiae Zinsmeister, 1977, but the sculpture on whorls of $R$. crassitesta is coarser and becomes abruptly finer on the siphonal neck, its columella is more flexed, and its anterior siphon more strongly deflected leftward. A fortuitously broken specimen that shows the columella well back from the aperture has three folds on the columella, two strong and one weak.

\section{RETIPIRULA PINGUIS new species}

Figure 11.13, 11.14

\section{Diagnosis.-Retipirula with very low spire.}

Description.-Shell medium-sized, roundly ovoid, flattened apically and elongated abapically by short, slightly twisted, anterior siphonal neck; spire barely elevated; suture undulated on first noded spiral cord of previous whorl; whorls expanding flatly; ramp barely concave and slightly sloped to first noded cord; whorl side roundly inflated, widest medially between third and fourth cord, constricted into broad siphonal neck. Protoconch turbinate, of three whorls. Growth line opistocyrt across ramp, slightly flexed across whorl flank, occasionally strong enough to disrupt costae. Sculpture of spiral cords and collabral costae; spiral cords narrower than interspaces, about seven strong spirals sharply noded at intersections with costae, eight (?) finer unnoded cords on siphonal neck; collabral costae extending from first noded cord to seventh cord. Aperture elongate, widest medially with slight posterior siphonal notch and moderate width anterior canal; outer lip evenly curved; inner lip callused with parietal callus expanded apically to first cord of previous whorl in early whorls and across ramp of previous whorl in mature specimens; four oblique folds near base of columella, two nearly equal, moderately strong, near base of columella, one weak, and one very weak anterior fold.

Etymology-Latin, pinguis, fat.

Types.-Holotype LACMIP 13222 from LACMIP 22701, Area 16. Paratypes 13223, 13224 from LACMIP 22701; 13225 from LACMIP 22574, Area 16.

Material examined.-Twenty-five specimens from Area 16; six specimens from redeposited cobble in Santa Susana Formation conglomerate bed on north side Simi Valley (LACMIP 7142), Santa Susana Mountains; nineteen specimens from Simi Hills, south side of Simi Valley.

Occurrence.-Early Paleocene. (Area 16) Santa Susana Mountains and Simi Hills, lower Santa Susana Formation; lower Paleocene.

Discussion.-Retipirula pinguis resembles $R$. crassitesta in overall sculpture and shape, but the whorl of $R$. pinguis is more roundly inflated posteriorly with more, narrower cords and costae, the intersections of which are marked by smaller nodes than on $R$. crassitesta. Whorls of $R$. pinguis overlap the posterior row of nodes of the previous whorl and have a broad, almost horizontal ramp which results in a shorter spire with a much wider pleural angle than in $R$. crassitesta.

The occurrence of $R$. pinguis with Turritella reversa Waring, 1917 , in redeposited boulders in Santa Susana Formation conglomerates, suggests that $R$. pinguis is of early Paleocene age.

\section{ACKNOWLEDGMENTS}

We thank the members of the Victoria Paleontology Society, Saanichton, British Columbia, for sending us excellent specimens with good locality data from the Nanaimo Group, Georgia Basin, British Columbia; B. J. Dougherty of the Geological Survey of Canada for the loan of Whiteaves' specimens from the Nanaimo Group, Sucia Island, which became the type lot for $V$. suciana Dall, 1907; D. L. Lindberg of the University of California, Berkeley, 
for the loan of types of Volutoderma santana Packard and V. magna; T. A. Demeré of the Natural History Museum of San Diego for the loan of excellent specimens of volutes from the Point Loma Formation; J. D. Cooper of California State University, Fullerton, for the loan of Orange County specimens; J. DeMouthe of California Academy of Sciences for access to CASG collections and loan of specimens; M. Kooser of University of California, Riverside for access to UCR collections and loan of specimens; R. Hilton of Sierra College for field assistance in the Pentz area and E. Göhre for field assistance and loan of specimens; L. Groves of Malacology at the Natural History Museum of Los Angeles County for loans and library assistance. We are also indebted to the late H. G. Richards of the Academy of Natural Sciences of Philadelphia for the loan of Gabb's specimens identified as Volutolithes navarroensis Shumard; and the late J. W. Durham and J. H. Peck of the University of California, Berkeley for the opportunity to study and make plaster casts of the type specimens of Fusus averillii Gabb, Volutoderma santana Packard, and V. magna Packard. We thank P. D. Ward for correcting ranges of ammonites, especially Baculites associated with Volutoderma.

\section{REFERENCES}

AbBass, H. L. 1963. A monograph on the Egyptian Cretaceous gastropods. United Arab Republic, Geological Survey and Mineral Research Department, Palaeontological Series, Monograph 2, $146 \mathrm{p}$.

ANDERSON, F M. 1902. Cretaceous deposits of the Pacific Coast. California Academy of Sciences Proceedings, series 3, 2:1-154, pls. 1-12

ANDERson, F. M. 1958. Upper Cretaceous of the Pacific Coast. Geological Society of America Memoir 71, 378 p., 75 pls.

ANDERSON, F. M. AND G. D. HANNA. 1935. Cretaceous geology of Lower California. California Academy of Sciences, Proceedings, series 4, 23(1): $1-34$.

ARNOLD, R. 1908. Descriptions of new Cretaceous and Tertiary fossils from the Santa Cruz Mountains, Californa. U.S. National Museum Proceedings, 34:345-390, pls. 31-37.

ARNold, R. 1910. Paleontology of the Coalinga District, Fresno and Kings Counties, California. United States Geological Survey Bulletin, 396, 173 p., 30 pls.

ARNOLD, R. AND R. ANDERSON. 1910. Geology and oil resources of the Coalinga District, Fresno and Kings counties, California. United States Geological Survey Bulletin, 398, 354 p., 52 pls.

BANDEL, K. 2000. Some gastropods from the Trichinopoly Group Tamil Nadu, India and their relation to those from the American Gulf Coast. Geological Society of India Memoir, 46:65-111.

BANDEL, K. 2003. Cretaceous volutid Neogastropoda from Western Desert of Egypt and their place within the Neogastropoda (Mollusca). Mitteilungen Geologisch-Paläontologisches Institut Universität Hamburg, 87:73-98.

BANDEL, K. AND D. T. DOCKERY. 2001. The Sarganidae (Pyrifusoidea, Latrogastropoda), their taxonomy and paleobiogeography. Journal of the Czech Geological Society, 46:335-351.

BoLTON, T. E. 1965. Catalogue of type invertebrate fossils of the Geological Survey of Canada. Volume II. Geological Survey of Canada, Ottawa, $344 \mathrm{p}$.

Bouchet, P., J. Fryda, B. Hausdorf, W. Punder, Á. Valdés, and A. WARÉN. 2005. Working classification of the Gastropoda, p. 239-284. In P. Bouchet and J.-P. Rocroi (eds.), Classification and Nomenclator of Gastropod Families. Malacologia, 47(1-2).

BRÉBION, P. 1956. Gasteropoda Cretacés du Bas-Congo, recoltes par H. Pierard. Annales du Musée Royal du Congo Belge Tervuren, Belgique, Sciences Géologiques, 17:81-93.

Butler, R. F, G. E. Gehrels, and K. P. Kodama. 2001. A moderate translation alternative to the Baja British Columbia hypothesis. GSA Today, $11(6): 4-9$.

Cl.ARK, B. L. 1929. Stratigraphy and faunal horizons of the Coast Ranges of California. Privately published, Berkeley, 132 p., 50 pls.

COBBAN, W. A. AND W. J. KeNNEDY. 1995. Maastrichtian ammonites chiefly from the Prairie Bluff Chalk in Alabama and Mississippi. The Paleontological Society Memoir 44 (Journal of Paleontology 69, no. 5 supplement III of III), $40 \mathrm{p}$.

Cossmann, M. 1896. Essais de Paléontologie Comparé. Privately published, Paris, tome 2, $176 \mathrm{p}$.

Cossmann, M. 1909. Essais de Paléontologie Comparé. Privately published, Paris, tome 8, $248 \mathrm{p}$.

Cuvier, G. L. C. 1797. Tableau Élémentaire de l'Histoire Naturelle des Animaux [des Mollusques]. Baudonin, Paris, $710 \mathrm{p}$.

DAILEY, D. H. AND W. P. POPENOE. 1966. Mollusca from the Upper Cretaceous Jalama Formation, Santa Barbara County, Califomia. University of California Publications in Geological Sciences, 65, $41 \mathrm{p}$.

DALL, W. H. 1890. Contributions to the Tertiary fauna of Florida with especial reference to the Miocene Silex beds of Tampa and the Pliocene beds of the Caloosahatchie River, Pt. 1. Wagner Free Institute of Science Transactions, 3:1-200.
Dall, W. H. 1907. Notes on some Upper Cretaceous Volutidae, with descriptions of new species and a revision of the groups to which they belong. Smithsonian Miscellaneous Collections, 50 (no. 1704):1-23.

Darragh, T. A. AND W. F. PONDER. 1998. Family Volutidae, p. 833-835. In P. L. Beesley, G. J. B. Ross, and A. Wells (eds.), Mollusca: The Southern Synthesis. Fauna of Australia, 5. CSIRO Publishing, Melbourne.

Dartvelle, E. AND P. Brébion. 1956. Mollusques fossiles du Crétacé de la Côte occidentale d'Afrique du Cameroun à l'Angola. Annales du Musée Royal du Congo Belge Tervuren, Belgique, Sciences Géologiques, 17:viii $+1-128$, pls. $1-8$.

Dickinson, W. R. AND R. F. BUTLER. 1998. Coastal and Baja California paleomagnetism reconsidered. Geological Society of America Bulletin, 110: $1268-1280$

DJALILOV, M. R. 1977. Cretaceous Gastropods from Southeastern Central Asia. Akademia Nauk Tadzhik SSR, 202 p. (In Russian)

D'OrbignY, A. 1842-1843. Paléontologie Française. Ser. 1. Animaux Invertébrés. Terrain Crétacés, 2, $456 \mathrm{p}$.

DzhaliLov, 1977, see Djalilov

ELDER, W. P. AND L. R. SAUl. 1993. Paleogeographic implications of molluscan assemblages in the Upper Cretaceous (Campanian) Pigeon Point Formation, California, p. 171-186. In G. Dunne and K. McDougall (eds.), Mesozoic Paleogeography of the Western United States-II, Pacific Section SEPM, Book 71.

ELDER, W. P. AND L. R. SAUL. 1996. Taxonomy and biostratigraphy of Coniacian through Maastrichtian Anchura (Gastropoda: Aporrhaiidae) of the North American Pacific Slope. Journal of Paleontology, 70:381-399.

Elder, W. P., L. R. SAul, AND C. L. Powell. 1998. Late Cretaceous and Paleocene molluscan fossils of the Gualala Block and their paleogeographic implications, p. 149-168. In W. P. Elder (ed.), Geology and Tectonics of the Gualala Block, Northern California, Pacific Section SEPM, Book 84.

Fisher, W. L., P. U. RODDA, AND J. W. DiETRICH. 1964. Evolution of Athleta petrosa stock (Eocene, Gastropoda) of Texas. University of Texas Publications, $6413,117 \mathrm{p}$

ForBEs, E. 1846. Report on the Cretaceous fossil invertebrates from southern India, collected by Mr. Kaye and Mr. Cunliffe. Geological Society of London Transactions [1845], series 2, 7:97-174.

FowkEs, E. J. 1982. An Educational Guidebook to the Geologic Resources of the Coalinga District, California. West Hills College, Coalinga, California, $260 \mathrm{p}$.

FRAKES, L. A. 1999. Estimating the global thermal state from Cretaceous sea surface and continental temperature data, p. 49-57. In E. Barrera and C. C. Johnson (eds.), Evolution of the Cretaceous Ocean-Climate System. Geological Society of America Special Paper 332.

GABB, W. M. 1864. Description of the Cretaceous fossils. California Geological Survey, Palæontology, 1:57-243, pls. 9-32.

GABB, W. M. 1866-1869. Cretaceous and Tertiary fossils. California Geological Survey, Palæontology, 2, 299 p.

GABB, W. M. 1877. Notes on American Cretaceous fossils, with descriptions of some new species. Academy of Natural Sciences of Philadelphia Proceedings, 28:276-324.

Gradstein, F. M., J. G. OGg, AND A. Smith. 2004. Geologic Time Scale. Cambridge University Press, Cambridge, 589 p.

HAGGART, J. W. 1986. Stratigraphy of the Redding Formation of North-Central California and its bearing on Late Cretaceous paleogeography, p. 161178. In P. L. Abbott (ed.), Cretaceous Paleogeography and Stratigraphy. SEPM Pacific Section, symposium volume, Book 46.

HaGGaRT, J. W. AND P. D. WARD. 1984. Late Cretaceous (Santonian-Campanian) stratigraphy of the northern Sacramento Valley, California. Geological Society of America Bulletin, 95:618-627.

HolzAPFEL, E. 1888-1889. Die Mollusken der Aachener Kreide. Palaeontographica, 34:29-80 (1888); 35:139-268 (1889).

ICZN. 1999. International Commission on Zoological Nomenclature. International Code of Zoological Nomenclature, (fourth edition). International Trust for Zoological Nomenclature, c/o Natural History Museum, London, $306 \mathrm{p}$.

JOHNSON, C. C. 1999. Evolution of Cretaceous surface current circulation patterns, Caribbean and Gulf of Mexico, p. 329-343. In E. Barrera and C. C. Johnson (eds.), Evolution of the Cretaceous Ocean-Climate System. Geological Society of America Special Paper 332

KIEL, S. AND K. BANDEL. 2003. New taxonomic data for the gastropod fauna of the Umzamba Formation (Santonian-Campanian, South Africa) based on newly collected material. Cretaceous Research, 24:449-475.

KIEL, S. AND F. J. KRüGER. 2006. Gastropoda aus dem Mittelsanton (Oberkreide) von Lengede (Niedersachen). Braunschweiger Naturkundliche Schriften, 7:677-696.

Kiel, S. And M. C. Perrilliat. 2004. New gastropods from the Maastrichtian of the Mexcala Formation in Guerrero, southern Mexico, Pt. III, Higher Caenogastropoda. Neues Jahrbuch für Geologie und Paläontologie, Abhandlungen, 231:191-217.

KODAMA, K. P. AND P. D. WARD. 2001. Compaction-corrected paleomagnetic 
paleolatitudes for Late Cretaceous rudists along the Cretaceous California margin: Evidence for less than $1500 \mathrm{~km}$ of post-Late Cretaceous offset for Baja British Columbia. Geological Society of America Bulletin, 113:11711178.

Kollmann, H. A. 2005. Révision critique de la Paléontologie Française d'Alcide d'Orbigny, Volume III Gastropodes Crétacés. Publication dirigée par J.-C. Fischer. Museum d'Histoire naturelle de Vienne, Autriche, Backhuys Publishers, Leiden, Pays-Bas, France, 239 p. + Rédition du Tome Second (Terrains crétacés, Gastropodes de la Paléontologie française d'Alcide d'Orbigny (édition original: 1842-1843) $454 \mathrm{p}$. + Atlas of pl. 149-236.

Ludvigsen, R. AND G. Beard. 1994. West Coast Fossils. Whitecap Books, Vancouver/Toronto, $194 \mathrm{p}$

LudvigSen, R. AND G. BEARD. 1997. West Coast Fossils (second edition). Harbour Publishing, Madiera Park, British Columbia, 216 p.

LUND, S. P. AND D. J. BoTTJER. 1992. Paleomagnetic evidence for microplate tectonic development of southern and Baja California, p. 231-248. In J. P. Dauphin and B. R. T. Simoneit (eds.), The Gulf and Peninsular Province of the Californias. American Association of Petroleum Geologists Memoir 47.

Matsumotro, T. 1959a. Upper Cretaceous ammonites of California, Pt. I. Kyushu University Faculty of Science Memoir, series D, Geology 8:91171.

Matsumoto, T. 1959b. Upper Cretaceous ammonites of California, Pt. II. Kyushu University Faculty of Science Memoir, series D, Geology, Special Volume 1, $172 \mathrm{p}$.

Matsumoto, T. 1960. Upper Cretaceous ammonites of California, Pt. III. Kyushu University Faculty of Science Memoir, series D, Geology, Special Volume 2, 204 p., 2 pls.

Matsumoto, T. 1984. Some ammonites from the Campanian (Upper Cretaceous) of Northern Hokkaido. Palaeontological Society of Japan Special Papers, 27, $93 \mathrm{p}$

MATsumoto, T. AND I. OBATA. 1963. A monograph of the Baculitidae from Japan. Kyushu University, Faculty of Science, Memoirs, series D, Geology, $13: 1-116$.

MEEK, F. B. 1858. Descriptions of new organic remains from the Cretaceous rocks of Vancouver's Island. Albany Institute, Transactions, 4:37-49 (1857).

MEEK, F. B. 1862. Descriptions of new Cretaceous fossils collected by the North-Western Boundary Commission, on Vancouver and Sucia Islands. Academy of Natural Sciences of Philadelphia Proceedings, 13:314-318.

Merriam, C. W. 1941. Fossil turritellas from the Pacific Coast region of North America. University of California Publications, Department of Geological Sciences Bulletin, 16:1-214.

MerRIAM, J. C. 1895. A list of type specimens in the Geological Museum of the University of California, etc. University of California, Geology Department, 3 printed, unnumbered pages. [Reprinted by A. W. Vogdes, 1896 , California State Mining Bureau, Bulletin 10, and 1904, California State Mining Bureau, Bulletin 3,]

MOR'TON, B. 1986. The diet and prey capture mechanism of Melo melo (Prosobranchia: Volutidae). Journal of Molluscan Studies, 51:156-160.

MORTON, S. G. 1834. Synopsis of the Organic Remains of the Cretaceous Group of the United States. Illustrated by nineteen plates, to which is added an appendix containing a tabular view of the Tertiary fossils discovered in America. Key and Biddle, Philadelphia, $88 \mathrm{p}$.

MüllLeR, J. 1851. Monographie der Petrefacten der Aachener Kreideformation, Pt. 2. J. J. Beaufort, Bonn, 88 p.

Nelson, R. N. 1925. A contribution to the paleontology of the Martinez Eocene of California. University of California Publications, Department of Geological Sciences Bulletin 15:397-466.

NiLSEN, T. H. 1984a. Tectonics and sedimentation of the Upper Cretaceous Hornbrook Formation, Oregon and California, p. 101-118. In J. K. Crouch and S. B. Bachman (eds.), Tectonics and sedimentation along the California margin. Society of Economic Paleontologists and Mineralogists, Pacific Section, Book 38

NILSEN, T. H. 1984b. Stratigraphy, sedimentology, and tectonic framework of the Upper Cretaceous Hornbrook Formation, Oregon and California, p. 5188. In T. H. Nilsen (ed.), Geology of the Upper Cretaceous Hornbrook Formation, Oregon and California. Society of Economic Paleontologists and Mineralogists, Pacific Section, 42.

PACKARD, E. L. 1922. New species from the Cretaceous of the Santa Ana Mountains, California. University of California Publications, Department of Geological Sciences, Bulletin, 13:413-462.

Pervinquière, L. 1912. Études de Paléontologie Tunisienne II, Gastropodes et lamellibranches des terrains Crétacés. Direction Générale des Travaux Publics, Carte Géologique de la Tunisie, Paris, 352 p. (Atlas), 23 pls.

PilsBry, H. A. AND A. A. Olsson. 1954. Systems of the Volutidae. Bulletins of American Paleontology, 35(152):275-306.

PONDER, W. F. AND A. WARÉN. 1988. Appendix. Classification of the Caenogastropoda and Heterostropha-A list of the family-group names and higher taxa, p. 288-328. In W. F. Ponder (ed.), Prosobranch Phylogeny. Malacological Review, Supplement 4.

POPENOE, W. P. 1937. Upper Cretaceous Mollusca from southern California Journal of Paleontology, 11:379-402.

POPENOE, W. P. 1942. Upper Cretaceous formations and faunas of Southern California. American Association of Petroleum Geologists Bulletin, 26: $162-187$

POPENOE, W. P. 1954. Mesozoic formations and faunas, southern California and northern Baja California, p. 15-21. In California Division of Mines, Bulletin 170, Chapter 3, (Historical Geology).

POPENOE, W. P. 1983. Cretaceous Aporrhaidae from California: Aporrhainae and Arrhoginae. Journal of Paleontology, 57:742-765.

POPENOE, W. P. AND L. R. SAUL. 1987. Evolution and classification of the Late Cretaceus-early Tertiary gastropod Perissitys. Natural History $\mathrm{Mu}$ seum of Los Angeles County, Contributions in Science, 380, $37 \mathrm{p}$.

RAFINESQUE, C. S. 1815. Analyses de la Nature ou Tableau de l'Universe et des Corps Organiseés. Barravecchia, Palermo, 224 p.

SAUL, L. R. 1973. Evidence for the origin of the Mactridae (Bivalvia) in the Cretaceous. University of California Publications in Geological Science, 97, $59 \mathrm{p}$.

SAUL, L. R. 1974. Described or figured West Coast species of Cymbophora. Journal of Paleontology, 48:1068-1095.

Saul, L. R. 1978. The North Pacific Cretaceous Trigoniid Genus Yaadia. University of California Publications in Geological Science, 119, $65 \mathrm{p}$.

SAUL, L. R. 1983. Turritella zonation across the Cretaceous-Tertiary boundary, California. University of California Publications in Geological Science, $125,164 \mathrm{p}$.

SAUL, L. R. AND J. M. Alderson. 1981. Late Cretaceous Mollusca of the Simi Hills: An introduction, p. 29-42. In M. H. Link, R. L. Squires, and I. P. Colburn (eds.), Simi Hills Cretaceous turbidites, Southern California. SEPM, Pacific Section, 1981 Fall Field Trip Guidebook. Los Angeles, California.

SAUL, L. R. AND D. J. BotTJER. 1982. Late Cretaceous megafossil locality map, northern Santa Ana Mountains, California, p. 77-79. In D. J. Bottjer, I. P. Colburn, and J. D. Cooper (eds.), Late Cretaceous Depositional Environments and Paleogeography, Santa Ana Mountains, Southern California. SEPM, Pacific Section, Annual Convention Field Guidebook \& Volume. Los Angeles, California.

SAUl, L. R. AND W. P. POPENOE. 1962. Meekia, enigmatic Cretaceous pelecypod genus. University of California Publications in Gelogical Science, 40: 289-344.

SaUl, L. R. AND W. P. Popenoe. 1993. Additions to Pacific Slope Turonian Gastropoda. The Veliger, 36:351-388.

SChENCK, H. G. AND A. M. Keen. 1940. California Fossils for the Field Geologists. Privately published and Stanford University Press, $86 \mathrm{p}$.

Schoellhamer, J. E., J. G. Vedder, R. F. Yerkes, and D. M. Kinney. 1981. Geology of the northern Santa Ana Mountains, California. U.S. Geological Survey, Professional Paper 420-D, $107 \mathrm{p}$.

SHImer, H. W. AND R. R. SHRock. 1944. Index Fossils of North America. John Wiley and Sons, New York, $837 \mathrm{p}$.

Shumard, B. F. 1861. Descriptions of new Cretaceous fossils from Texas. Boston Society of Natural History Proceedings, 8:188-205.

SMITH, J. P. 1900 . The development and phylogeny of Placenticeras. California Academy of Sciences Proceedings, series 3, 1:80-240.

SoHL, N. F. 1964. Neogastropoda, Opisthobranchia and Basommatophora from the Ripley, Owl Creek, and Prairie Bluff formations. U.S. Geological Survey Professional Paper, 331-B:i-iv, 153-344, pls. 19-52.

SoHL, N. F. 1987. Cretaceous Gastropods: Contrasts between Tethys and the temperate provinces. Journal of Paleontology, 61:1085-1111.

SpATH, L. F. 1926. On new ammonites from the English Chalk. Geological Magazine, 63:77-83.

SQuiRES, R. L. 1981. Geologic map of Upper Cretaceous Chatsworth Formation, Simi Hills, California (with fossil localities), map in pocket. In M. N. Link, R. L. Squires, and I. P. Colburn (eds.), Simi Hills Cretaceous turbidites, Southern California. SEPM, Pacific Section, Guidebook Fall Field Trip 1981. Los Angeles, California.

SQuiRes, R. L. AND L. R. SAUL. 2006. Cretaceous Acila (Truncacila) (Bivalvia: Nuculidae) from the Pacific Slope of North America. The Veliger, 48(1):32-53.

STEPHENSON, L. W. 1941. The larger invertebrate fossils of the Navarto Group of Texas. University of Texas Publications, no. 4101, $641 \mathrm{p}$.

STEPHENSON, L. W. 1952. Larger invertebrate fossils of the Woodbine Formation (Cenomanian) of Texas. U.S. Geological Survey, Professional Paper $242,226 \mathrm{p}$.

STEWART, R. B. 1927. Gabb's California fossil type gastropods. Academy of Natural Sciences of Philadelphia, Proceedings, 78:287-447.

STOLICZKA, F 1867-1868. Cretaceous Fauna of Southern India, 2. The Gastropoda. Geological Survey of India, Memoirs, Palæontologia Indica, series 5, 497 p. 
Sundberg, F. A. AND B. Riney. 1984. Preliminary report on the Upper Cretaceous macro-invertebrate faunas near Carlsbad, California, p. 103-107. In P. L. Abbott (ed.), Upper Cretaceous Depositional Systems Southern California-Northern Baja California. SEPM, Pacific Section, Volume and Guidebook, Book 36. Los Angeles, California.

TAliaferro, N. L. 1944. Cretaceous and Paleocene of Santa Lucia Range, California. American Association of Petroleum Geologists Bulletin, 28: 449-521.

WADE, B. 1916. New genera and species of Gastropoda from the Upper Cretaceous. Academy of Natural Sciences, Philadelphia, Proceedings, 68:455471.

WADE, B. 1926. The fauna of the Ripley Formation on Coon Creek, Tennessee. U.S. Geological Survey Professional Paper, 137, 272 p.

WARD, P. D. 1978a. Revisions to the stratigraphy and biochronology of the Upper Cretaceous Nanaimo Group, British Columbia and Washington State. Canadian Journal of Earth Sciences, 15:405-423.

WARD, P. D. 1978b. Baculitids from the Santonian-Maestrichtian Nanaimo Group, British Columbia, Canada and Washington State, USA. Journal of Paleontology, 52:1143-1154.

Ward, P. D., K. Verusub, and J. W. HagGart. 1983. Marine magnetic anomaly 33-34 identified in the Upper Cretaceous of the Great Valley Sequence of California. Geology, 11:90-93.

Ward, P. D., J. M. Hurtado, J. L. Kirschvink, and K. L. Verosub. 1997. Measurements of the Cretaceous paleolatitude of Vancouver Island: Consistent with the Baja-British Columbia hypothesis. Science, 277:1642-1645.

WARING, C. A. 1917. Stratigraphic and faunal relations of the Martinez to the Chico and Tejon of southern California. California Academy of Sciences Proceedings, series 4, 7:41-124.

WeAVer, C. E. 1953. Eocene and Paleocene deposits at Martinez, California. University of Washington Publications in Geology, 7:1-102.

Weaver, C. S. AND J. E. DU Pont. 1970. Living Volutes. Delaware Museum of Natural History, Greenville, Delaware, Monograph 1, 375 p.

Webster, M. L. 1983. New species of Xenophora and Anchura (Mollusca:
Gastropoda) from the Cretaceous of Baja California Norte, Mexico. Journal of Paleontology, 57:1090-1097.

Wenz, W. 1943. Gastropoda. Superfamily Volutacea, p. 1266-1380. In O. H. Schindewolf (ed.), Handbuch der Paläozoologie, Band 6, Gastropoda. Allgemeiner Teil und Prosobranchia, Teil 6, Gebrüder Borntraeger, Berlin. [Reprinted 1960-1961]

WHITE, C. A. 1889. Invertebrate fossils from California, Oregon, Washington, and Alaska. U.S. Geological Survey Bulletin, 51, 102 p.

WHITEAVES, J. F. 1879. On the fossils of the Cretaceous rocks of Vancouver and adjacent islands in the Strait of Georgia. Canada Geological Survey, Mesozoic Fossils, 1:191-262.

WHITEAVES, J. F. 1903. On some additional fossils from the Vancouver Cretaceous, with a revised list of species therefrom. Canada Geological Survey, Mesozoic Fossils, 1:309-415.

YABE, H. AND T. NAGAO. 1925. New or little known Cretaceous fossils from north Saghalin. Tohoku Imperial University, Science Report, series 2 (Geology), 7:111-124.

YABE, H. AND T. NAGAO. 1928. Cretaceous fossils from Hokkaido: Annelida, Gastropoda, and Lamellibranchiata. Tohoku Imperial University, Science Reports, series 2 (Geology), 9:77-96.

YABE, H. AND S. SHImIzU. 1921. Notes on some Cretaceous ammonites from Japan and California. Tohoku Imperial University, Science Reports, series 2 (Geology), 5:53-59.

ZINSMEISTER, W. J. 1977. First occurrence of Volutocorbis Dall in the Tertiary of western North America and a review of the subgenus Retipirula Dall (Mollusca: Gastropoda). Journal of Paleontology, 51:177-180.

Zinsmeister, W. J. AND L. M. PAREDes-MeJia. 1988. Paleocene biogeography of the West Coast of North America: A look at the molluscan fauna from Sepultura Formation, Mesa San Carlos, Baja California Norte, p. 922. In M. V. Filewicz and R. L. Squires, Paleocene Stratigraphy, West Coast of North America. SEPM, Pacific Section, Symposium Volume for April 17-19, 1988 Annual Meeting, Santa Barbara, California, Book 58.

ACCEPTED 30 MAY 2007 